\title{
Vascular endothelial growth factor A: just one of multiple mechanisms for sex-specific vascular development within the testis?
}

\section{Kevin M Sargent, Renee M McFee, Renata Spuri Gomes and Andrea S Cupp}

Department of Animal Science, University of Nebraska-Lincoln, Animal Science Building, 3940 Fair Street, Lincoln, Nebraska 68583-0908, USA
Correspondence should be addressed

to A S Cupp

Email

acupp2@unl.edu

\begin{abstract}
Testis development from an indifferent gonad is a critical step in embryogenesis. A hallmark of testis differentiation is sex-specific vascularization that occurs as endothelial cells migrate from the adjacent mesonephros into the testis to surround Sertoli-germ cell aggregates and induce seminiferous cord formation. Many in vitro experiments have demonstrated that vascular endothelial growth factor A (VEGFA) is a critical regulator of this process. Both inhibitors to VEGFA signal transduction and excess VEGFA isoforms in testis organ cultures impaired vascular development and seminiferous cord formation. However, in vivo models using mice which selectively eliminated all VEGFA isoforms: in Sertoli and germ cells (pDmrt1-Cre; Vegfa ${ }^{-1-}$ ); Sertoli and Leydig cells (Amhr2-Cre; Vegfa ${ }^{-1-}$ ) or Sertoli cells (AmhCre;Vegfa ${ }^{-1-}$ and Sry-Cre;Vegfa ${ }^{-1-}$ ) displayed testes with observably normal cords and vasculature at postnatal day 0 and onwards. Embryonic testis development may be delayed in these mice; however, the postnatal data indicate that VEGFA isoforms secreted from Sertoli, Leydig or germ cells are not required for testis morphogenesis within the mouse. A Vegfa signal transduction array was employed on postnatal testes from Sry-Cre;Vegfa ${ }^{-1-}$ versus controls. Ptgs1 (Cox1) was the only upregulated gene (fivefold). COX1 stimulates angiogenesis and upregulates, VEGFA, Prostaglandin E2 (PGE2) and PGD2. Thus, other gene pathways may compensate for VEGFA loss, similar to multiple independent mechanisms to maintain SOX9 expression. Multiple independent mechanism that induce vascular development in the testis may contribute to and safeguard the sex-specific vasculature development responsible for inducing seminiferous cord formation, thus ensuring appropriate testis morphogenesis in the male.
\end{abstract}

Key Words

- VEGFA

- testis

- sex differentiation

- vasculature
Journal of Endocrinology (2015) 227, R31-R50

\section{Introduction}

For years, many scientists have been investigating the factors responsible for inducing endothelial cell migration from the adjacent mesonephros into the developing indifferent gonad. Endothelial cell migration and vascular development has been demonstrated as one of the first steps for directing seminiferous cord formation and initiating the testis differentiation pathway (Tilmann \& Capel 1999, Albrecht et al. 2000). Within this review

Published by Bioscientifica Ltd 
we will discuss the reasoning behind investigating vascular endothelial growth factor A (VEGFA), its everevolving complexity due to transcriptional and posttranslational regulation, and how it acts on cells through multiple receptors and co-receptors as indicated mainly by rodent models (Qiu et al. 2009, Vieira et al. 2010, Dehghanian et al. 2014). Since infertility in the human male has been on the rise for almost 50 years (Carlsen et al. 1992, 1993, 1995, Juul et al. 2014), more information into gonadal development and how fertility is affected when mutations arise is critical to developing therapies for male related infertility issues. In the last decade, there have also been interesting data to suggest that male infertility may be associated with other health risks, since men with subnormal sperm counts also had reduced lifespans when evaluated between 1949 and 1985. This correlation between infertility and shorter lifespans in men may be due to lifestyle and behavior choices, conditions in utero or their genetic composition (Groos et al. 2006). There have been numerous incidences reported in the scientific literature of prenatal exposure to compounds that alter gene expression through epigenetic mechanisms and may affect reproduction and a host of other critical functions (e.g., immune). Thus, prenatal or inutero conditions may be one avenue that can be altered to increase reproductive function in men and also improve their lifelong health status. Since an altered uterine environment may influence gene expression that is necessary for testis development, any additional information on how testes develop may also increase our ability to develop measures to diagnose male infertility disorders that arise through prenatal programming or epigenetic causes.

\section{How does a testis develop from an indifferent gonad?}

The Sertoli cell expresses Sry (sex-determining region of the $\mathrm{Y}$ chromosome, a gene that is on the short arm of the $\mathrm{Y}$ chromosome) and is the first cell to differentiate in the testis (Magre \& Jost 1991). In the mouse, Sry is only briefly expressed (E10.5 to 12.5) and its primary function is the upregulation of Sox9 (SRY-box 9) (Harley et al. 2003). Much of the fate of the developing testis appears to be reliant on appropriate Sertoli cell differentiation and on the ability of Sox9 expression to be maintained at high levels (Fig. 1), thereby leading to the transcription of many genes to initiate testis development (Harley et al. 2003). Furthermore, expression of Sox9 upregulates other genes such as fibroblast growth factor 9 ( $F g f 9$ ) which, in addition to cementing the testis differentiation pathway, may antagonize genes such as wingless type MMTV integration site family, member 4 (Wnt4), that if overexpressed or not antagonized will enable the development of the female pathway (Shan et al. 2009, Jameson et al. 2012) (Fig. 1).

\section{What is the origin of the Sertoli cell ...a cell that is thought to direct testis development?}

The precursors of the Sertoli cells are the early somatic progenitor cells that develop from the coelomic epithelium. The coelomic epithelium is derived from the mesonephros and thickens as it differentiates, a phenomenon proposed to be due to gene expression of Sry. Many different transcription factors are critical for the proper development of the gonadal primordium that is enveloped by the coelomic epithelium such as EMX2 (empty spiracles homeobox 2), WT1, NR5A1 (nuclear receptor subfamily 5, group A, member 1, formerly SF1), LHX9 (LIM homeobox protein 9), GATA4 (GATA binding protein 4), ZFPM2/FOG2 (zinc finger protein, multitype 2 ) and others (Wilhelm et al. 2007, Munger \& Capel 2012). Both the thickening of the gonadal primordium to form the coelomic epithelium and the expression of Sry are critical to allow Sertoli cells to develop. At least $20 \%$ of the Sertoli cells need to express Sry in order for a testis to arise from the indifferent gonad (Patek et al. 1991, Burgoyne et al. 1995) (Fig. 1). Furthermore, Sox9 has to be upregulated by E11.2 through the actions of Sry for testis development to continue; if Sox 9 is not upregulated, then the proliferation of the Sertoli cells will arrest along with testis development (Fig. 1). In other species such as domestic livestock, Sry is maintained much longer and appears to have other functions (Pelliniemi \& Lauteala 1981, Daneau et al. 1996, Payen et al. 1996, Parma et al. 1999).

\section{Sox 9}

Originally, Sox9 is expressed in the indifferent gonad by the pre-Sertoli/granulosa cells and is transcribed at a very low copy number by SF1. When Sry is expressed, Sox9 is upregulated in the testis and its expression is silenced in the ovary (Kobayashi et al. 2005). Because Sry expression is short-lived, it is critical that other factors continue to upregulate and maintain Sox9 expression (Fig. 1). Sox9 induces the expression of $F f g 9$ and prostaglandin D2 synthase (Ptgds), in which the latter generates PGD2 (Wilhelm et al. 2007). One function of both of these genes is to maintain upregulated Sox 9 expression (Rossitto et al. 2015). Furthermore, Sox9 also upregulates itself through two mechanisms. It binds its own enhancer in

Published by Bioscientifica Ltd. 
A

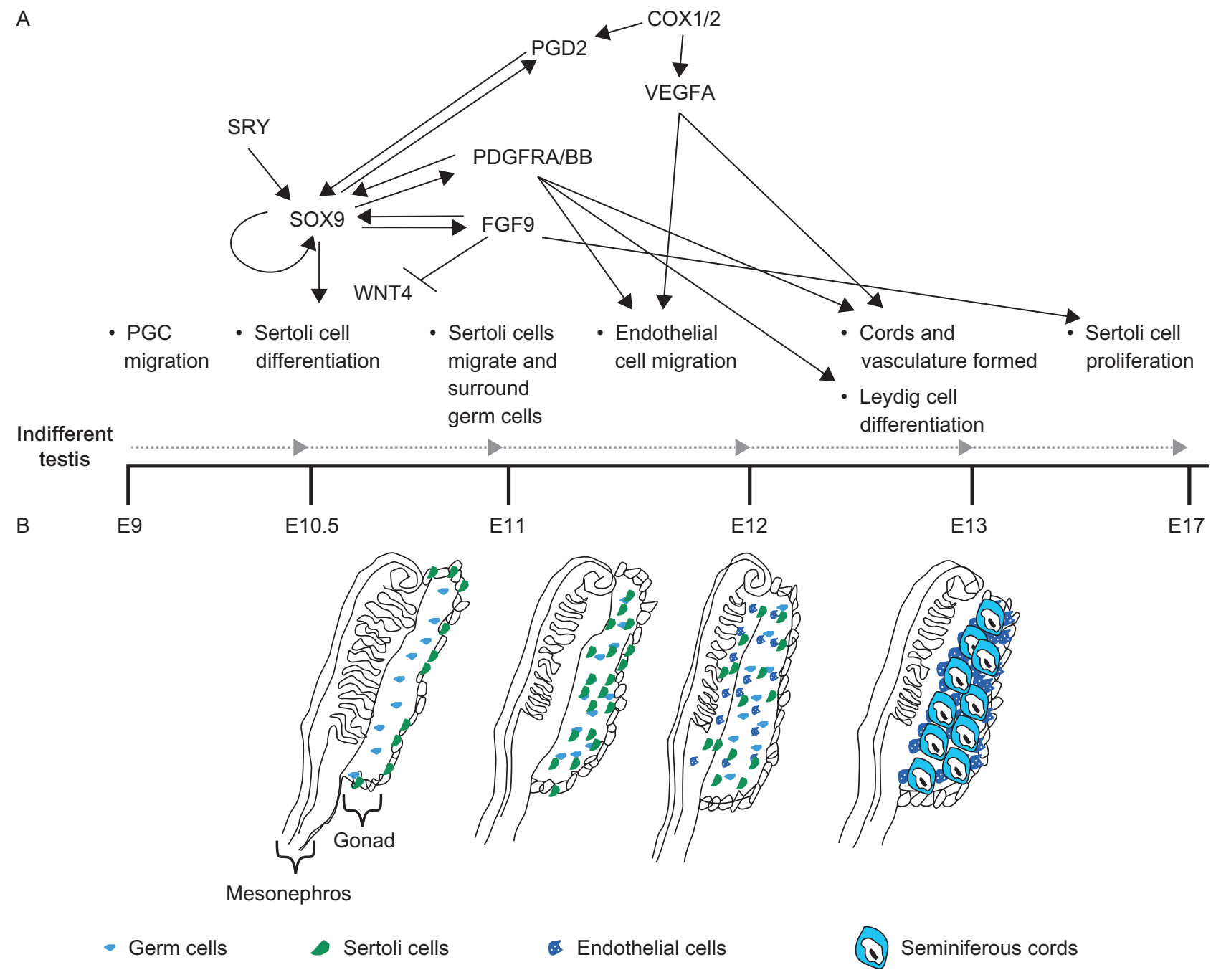

\section{Figure 1}

Gene expression during testis morphogenesis. Depicted above the timeline is a network pieced together based on gene and protein interactions in the literature related to sex-specific vascular development and sexual differentiation. The bottom of the figure depicts different stages of testis development. PGC, primordial germ cell; SRY, sex determining region of

a feed-forward fashion (Sekido \& Lovell-Badge 2008) and by maintaining upregulation of a transcription factor ER71/ETV2 (ets variant 2) that is initially increased through Sry expression (DiTacchio et al. 2012).

\section{FGF9}

Elimination of FGF9 or its receptor FGFR2 (fibroblast growth factor receptor 2) can cause male-to-female sex reversal given that FGF9 downregulates or suppresses the Wnt pathway that would otherwise promote female gonadal development (Vainio et al. 1999, Colvin et al. 2001, Jeays-Ward et al. 2003, Bagheri-Fam et al. 2008, Jameson
Chr Y; SOX9, SRY (sex determining region Y)-box 9; WNT4, wingless-type MMTV integration site family; member 4; PGD2, prostaglandin D2; PDGFR, platelet derived growth factor receptor; FGF9, fibroblast growth factor 9; COX, cyclooxygenase 1/2; VEGFA, vascular endothelial growth factor $A$.

et al. 2012, Siggers et al. 2014) (Fig. 1). Wnt4 knockout mice are sex-reversed similarly to knockouts of FGF9 (Shan et al. 2009). It was determined that FGF9 antagonizes the actions of WNT4 and thus prevents the ovarian pathway and allows for seminiferous cords to develop (Kim et al. 2006, Jameson et al. 2012). FGF9 also is critical for Sertoli cell proliferation necessary to provide enough Sertoli cells to differentiate to form clusters with germ cells.

\section{PGD2}

The gene-encoding Ptgds (Lipocalin-type Ptgds), an enzyme that produces PGD2, was identified in 2002 to

Published by Bioscientifica Ltd. 


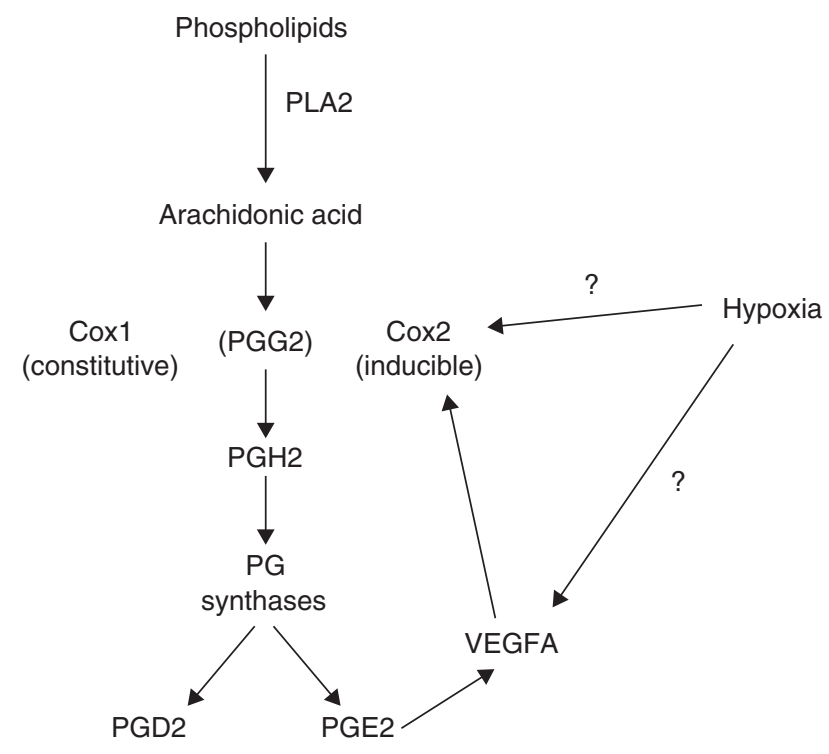

Figure 2

Proposed pathway of prostaglandin synthesis and interaction with the cyclooxygenase pathways and VEGFA. PLA2, phospholipase A2; PG, prostaglandin; COX, cyclooxygenase; VEGFA, vascular endothelial growth factor $A$.

be initially expressed in the developing urogenital ridges and later in Sertoli cells and prospermatogonia at around E11.5 (Adams \& McLaren 2002) (Fig. 1). Expression of the Ptgds gene in the developing testis was noted to be in a similar pattern as both Sry and Sox9 starting at the center and moving to the anterior poles in the developing testis (Wilhelm et al. 2007). Furthermore, expression of the PTGS protein was present in E12.5 male gonads in both Sertoli and germ cells (Moniot et al. 2009) that it is regulated upstream through either COX1 (cyclooxygenase 1) or COX2 pathways (Rossitto et al. 2015). However, neither male Cox2- nor Cox1-knockout mice are infertile; thus, there may be multiple ways to promote the production of PTGS in order to have a sufficient quantity of PGD2 (Gerena et al. 2000a,b). PTGDS is upregulated by Sox9 but not Sry (Wilhelm et al. 2007). PGD2 acts through its receptor, DP1 (prostaglandin D2 receptor 1) in Sertoli cells, to translocate the cytoplasmic SOX9 protein to the nucleus to influence gene expression.

\section{How is PGD2 regulated?}

Many endocrine disruptors such as phthalates, bisphenol and NSAIDS that inhibit COX activities also reduce PGD2 production as demonstrated in a mouse Sertoli cell line and fetal testis cultures (Kristensen et al. 2011a,b, 2012). Thus, it appears that the COX signaling pathway is involved and potentially downstream of SOX9 to induce expression of PGD2. In addition to PGD2, COX1 and 2 can stimulate upregulation of other prostaglandins such as PGE2, which is proangiogenic, and can further enhance the expression of VEGFA (Cheng et al. 1998, Pai et al. 2001). Furthermore, there appears to be a positive feedback pathway between COX2 and VEGFA with each of them increasing the other's expression as well as VEGFA upregulating upstream factors in the arachidonic pathway to further enhance COX2 activity. COX1 is thought to be constitutively expressed while most of the effects of hypoxia and VEGFA may be through stimulation of the inducible COX2 (Iniguez et al. 2003) (Fig. 2). Since, angiogenic inhibitors do not appear to inhibit COX1; it is possible that the constitutively-expressed COX1 may safeguard some function of angiogenesis within the developing testes.

\section{Mesonephric cell migration directs testis development: are the migrating mesonephric cells peritubular myoid cells or endothelial cells?}

As Sertoli cells differentiate and establish intimate contact with germ cells, they form clusters with germ cells aptly named Sertoli-germ cell clusters (Tesarik et al. 2002). Germ cells are of extragonadal origin and migrate to the indifferent gonad prior to Sertoli cell differentiation (Mintz \& Russell 1957, Ozdzenski 1969). Germ cells do not appear to induce seminiferous cord formation since cord formation still occurs in the testis of Kit (kit oncogene, also known as c-Kit) knockout despite a lack of primordial germ cells migration to and colonization of the indifferent gonad (Nocka et al. 1989, Runyan et al. 2006).

Very elegant studies have demonstrated that mesonephric cells migrating from the mesonephros are necessary for cord formation and later that the developing testis from an indifferent gonad directs mesonephric cell migration (Buehr et al. 1993). This migration can even pass through an ovary inserted between the mesonephros and the developing testis (Tilmann \& Capel 1999). Initially the migrating cells were thought to be pre-peritubular myoid cells since that cell type is what forms around seminiferous cords and aids later in development of the blood-testis barrier (Buehr et al. 1993). However, others have demonstrated that all cells that migrated are endothelial cells (Cool et al. 2008, Combes et al. 2009).

Since the Sertoli cells are the first cell to differentiate in the testis (Magre \& Jost 1991), they were thought to be the

Published by Bioscientifica Ltd 
catalyst for induction of endothelial cell migration via secretion of factors that serve as chemoattractants for mesonephric cells. Later it was determined that mesonephric cell migration not only directs seminiferous cord formation but also may induce proliferation of the somatic cells up to a certain threshold to restrict their number. Early studies identified factors that had receptors within peritubular myoid (PTM) cells such as neurotrophins (NT) (Levine et al. 2000) and PDGFs (Puglianiello et al. 2004). The low affinity receptor for the neurotrophins, NGFR (nerve growth factor receptor), is expressed in cells which appear to migrate from the mesonephros into the differentiating testis and by P0 it is only expressed in a thin layer of cells which appear to have differentiated into the PTM layer that surrounds each seminiferous cord (Russo et al. 1999). Other experiments demonstrated that NT3 may be involved in mesonephric cell migration and TrkA and $\mathrm{C}$ (tyrosine receptor kinase) knockout mice contained fewer cords within the testis than WT mice, in addition to some fused or odd shaped cords (Cupp et al. 2002, Cupp et al. 2003).

The focus then became the endothelial cells because most of the cells that migrate from the mesonephros contained endothelial cell markers. In addition, sex-specific vasculature develops in the testis and ovary with large differences noted in vascular reorganization and origin in the testis compared to the ovary (Cool et al. 2008, Combes et al. 2009, Bott et al. 2010). It was postulated Sertoli cells produced angiogenic or vascular-specific factors to induce endothelial cell migration and cause sex-specific vascular development and seminiferous cord formation (Tilmann \& Capel 1999, Bott et al. 2010). Again the question was what angiogenic or vascular-specific factors were produced by the Sertoli cells around the time of sex-specific vasculature development and seminiferous cord formation?

\section{What composes the VEGFA ligand receptor family and how does VEGFA signal through its receptors and co-receptors?}

The VEGF family was a logical growth factor family to evaluate its involvement in endothelial cell migration within the developing testis due to its ability to stimulate endothelial cell migration, survival, proliferation and differentiation to initiate vasculogenesis and angiogenesis within developing organs and tumors (Ferrara et al. 2003, Lee et al. 2015). The VEGF family is composed of VEGFA, VEGFB, VEGFC, VEGFD, and PGF (Placental Growth Factor, previously known as PIGF). VEGFA is the most studied family member and is critical for angiogenic processes (Ferrara et al. 2003). Even the disruption of one allele (heterozygotic deletion) causes embryonic lethality between E11and E12. Since neovascularization does not occur in these mice, this suggests that the embryonic lethality is due to a lack of oxygen and nutrients delivery to organs and that VEGFA is critical for most organ functions (Ferrara et al. 1996).

\section{What are the receptors to which VEGFA binds?}

VEGFA binds to two different tyrosine kinase receptors: kinase insert domain protein receptor (KDR also known as VEGFR2 and FLK1), and FMS-like tyrosine kinase 1 (FLT1, also known as VEGFR1) (Ferrara et al. 2003). Both the KDR and the FLT1 receptors contain an extracellular domain comprised of seven immunoglobulin-like (Ig-like) folds (Fig. 3). The function of the Ig-like folds were determined through mutation experiments indicating the VEGFA high affinity ligand binding domain is within the second and third folds while the first and fourth Ig-like fold regulate the ability for the ligand to bind and the receptor to dimerize (Davis-Smyth et al. 1998, Fuh et al. 1998, Shinkai et al. 1998, Vieira et al. 2010). The KDR receptor is the primary receptor that VEGFA signals through (Waltenberger et al. 1994, Seetharam et al. 1995, Kroll \& Waltenberger 1997, Wheeler-Jones et al. 1997, Cunningham et al. 1999). This is mainly due to the observation that the tyrosine phosphorylation sites on the FLT1 receptor (in the regulatory juxtamembrane domain and five within the C-terminus; Fig. 3) are never phosphorylated when the VEGFA ligand binds endothelial cells.

\section{FLT1 receptor - why is it called the decoy receptor?}

FLT1 has higher affinity for VEGFA than KDR (Waltenberger et al. 1994, Olofsson et al. 1998, Gille et al. 2001). Since there was no phosphorylation of its tyrosine residues the main function of this receptor was thought to be to function as a decoy receptor for VEGFA and, thus, to inhibit VEGFA-KDR ligand-receptor interactions and subsequent signal transduction. Presumably this was to allow for inhibition of vascularization of tissues (Ferrara 2000, Zachary \& Gliki 2001). This is supported by a study demonstrating that FLT1/VEGFR1 knockout mice that die at E8 and E9 is due to a failure of endothelial cells to assemble into a vasculature circuit (Fong et al. 1995). Since most KDR-mediated VEGFA binding results in vascularization of tissues, an increase in FLT1 production to inhibit binding to KDR may be a method to regulate

Published by Bioscientifica Ltd 


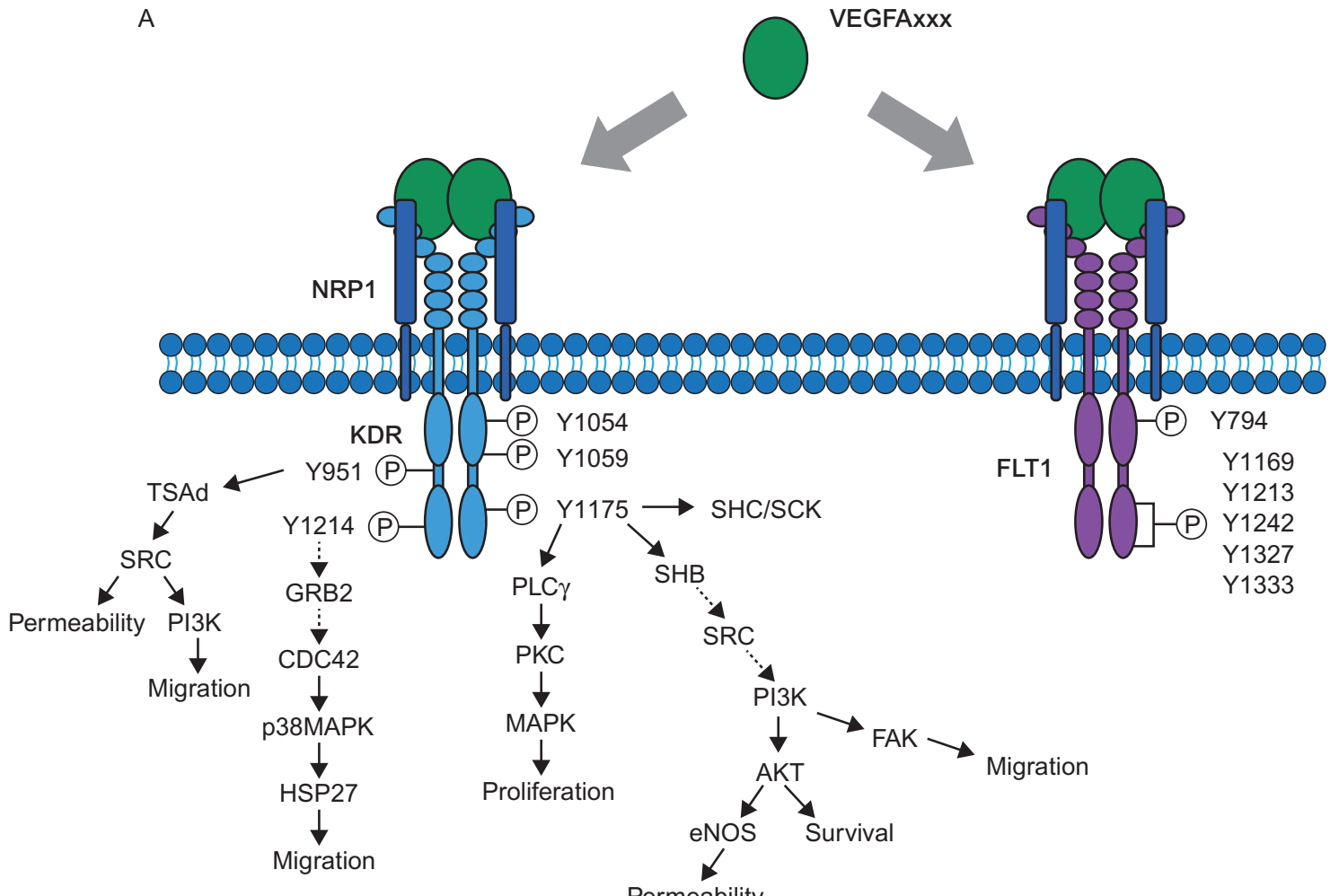

B

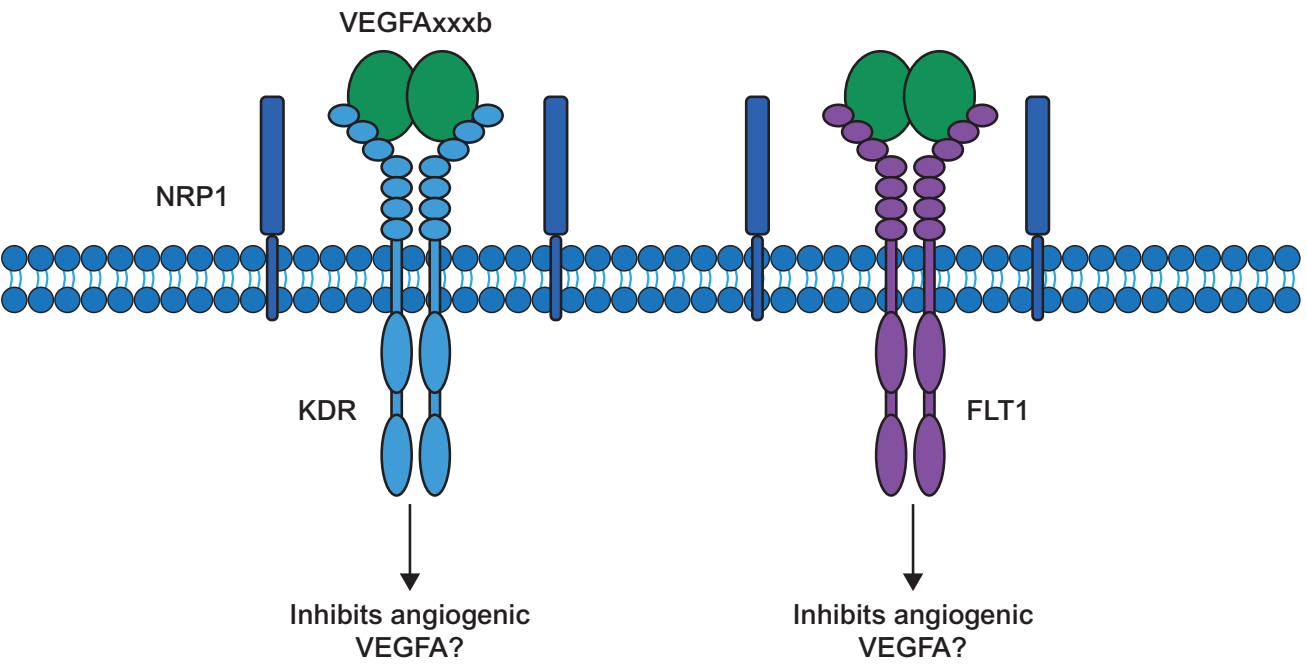

\section{Figure 3}

VEGF receptors critical to the actions of VEGFA. Pictured is the binding of angiogenic VEGFA isoforms to either KDR (top right) or FLT1 (top left). Only angiogenic isoforms of VEGFA bind to NRP1 (top). Antiangiogenic VEGFA isoform binding to either KDR (bottom left) or FLT1 (bottom right) results in less and different signal transduction than angiogenic. Antiangiogenic VEGFA isoforms are unable to bind NRP1 (bottom). Phosphorylation sties are depicted as ' $P$ ' within a circle. $Y$, tyrosine; VEGFA, vascular endothelial growth factor $A ; K D R$, kinase insert domain protein receptor; FLT1, fms-like tyrosine kinase 1; NRP1, neuropilin 1; TSAd, T-cell specific adaptor;
SRC, Rous sarcoma oncogene; PI3K, phosphatidylinositol 3-kinase; GRB2, growth factor receptor bound protein 2; CDC42, cell division cycle 42; (p38)MAPK, mitogen-activated protein kinase; HSP27, heat shock protein 27; PLCgamma, phospholipase C gamma; PKC, protein kinase C; SHC/SCK, src homology 2 domain-containing transforming protein; $\mathrm{SHB}$, src homology 2 domain-containing transforming protein B; AKT, thymoma viral proto-oncogene; eNOS, nitric oxide synthase 3; endothelial cell; FAK, focal adhesion kinase. 
vascularization. Recent reports have also suggested that FLT1 may prevent endothelial cell apoptosis and thus is a potential survival factor (Vieira et al. 2010). This may be due to FLT1 but not KDR being regulated by hypoxia. Within the promoter region of the FLT1 receptor is a binding site for hypoxia inducible factor 1 , alpha subunit (HIF1A) (Gerber et al. 1997). Thus, FLT1 expression along with upregulation of VEGFA through hypoxia (since there is a HIF1A promoter site in the VEGFA promoter, as well) may allow for survival of these cells and stimulation of some sort of vascular growth to provide oxygen to the tissue. Due to alternative splicing, FLT1 is not only present in a membrane-bound form but also has a soluble form (sFLT1) that acts similarly to binding proteins. Thus this soluble form may also act as a decoy receptor to sequester VEGFA away from KDR (Kearney et al. 2004). An increase in sFLT1 has been demonstrated to occur in pathological states such as preeclampsia (Hiratsuka et al. 2001, Autiero et al. 2003). Thus, regulation of the soluble as well as membrane forms of FLT1 are critical to allow for appropriate vascularization of tissues.

\section{FLT1 signaling pathways}

FLT1 contains several potential tyrosine autophosphorylation sites in the c-terminus and also juxtamembrane transmembrane domain. These sites are suppressed by a repressor element located in the juxtamembrane domain, which inhibits the phosphorylation of these tyrosine residues after VEGFA binding (Gille et al. 2000). However, in monocytes and macrophages this repression is not present and there is no information to suggest how this occurs other than the secretion of factors that relieve this inhibition. Thus, in these particular cell types, FLT1 can recruit several different accessory proteins such as protein kinases related to SRC (Rous sarcoma oncogene), FYN (fyn proto-oncogene) and YES1 (Yamaguchi sarcoma viral (v-yes) oncogene homolog 1) (Chou et al. 2002).

\section{Does FLT1 signal in the somatic cells of the testis or is it repressed similarly to endothelial cells?}

Caires et al. (2012) demonstrated that there was increased phosphorylation of tyrosine $(\mathrm{Y}) 1333$ within the FLT1 receptor in somatic cells at postnatal day 3 (P3) in mice compared to activation in gonocytes, Sertoli and Leydig cells at P1 (Caires et al. 2012). Also, inhibitors that blocked both FLT1 and KDR simultaneously were effective in testis organ cultures in inhibiting both sex-specific vascular development as well as seminiferous cord formation (Bott et al. 2006) (Table 1). To our knowledge, no experiments have been conducted to determine if FLT1 signals in the somatic or germ cells of the testis early in development, but it is possible that this occurs. Since FLT1 is not present until after seminiferous cord formation in the testis (Bott et al. 2006), it may not be critical. However, since FLT1 can be upregulated by hypoxia, it may be a failsafe mechanism to initiate neovascularization in some tissues outside the testis where VEGFA or KDR are limiting and vascularization of the tissue is critical for survival.

\section{Why is KDR thought to be the primary receptor through which VEGFA signals?}

In contrast to FLT1, the KDR receptor is autophosphorylated on several tyrosine residues after ligand binding and receptor dimerization that have been depicted in the human in the kinase insert domain (Fig. 3): Y951 (Y949

Table 1 Signal transduction inhibitors of VEGFA signaling and their effects on rat embryonic testis cord formation and vascular development in vitro (data from Bott et al. (2006))

\begin{tabular}{|c|c|c|}
\hline $\begin{array}{l}\text { Signal transduction } \\
\text { pathway }\end{array}$ & Inhibitor & $\begin{array}{l}\text { Effect on cord } \\
\text { formation }\end{array}$ \\
\hline Inhibits KDR & $\begin{array}{l}\text { SU1498 (Calbiochem, } \\
\text { \#572888) }\end{array}$ & No cord formation \\
\hline Inhibits KDR and FLT1 & $\begin{array}{l}\text { VEGF-TKI (Calbiochem, } \\
\text { \#676475) }\end{array}$ & No cord formation \\
\hline Inhibits NRP1 & $\begin{array}{l}\text { Je11 (Calbiochem, } \\
\text { \#676494) }\end{array}$ & $\begin{array}{l}\text { No cords/perturbed cord } \\
\text { formation }\end{array}$ \\
\hline Inhibits PI3K & $\begin{array}{l}\text { LY294002 (Calbiochem, } \\
\quad \text { \#440202) }\end{array}$ & $\begin{array}{l}\text { Cords perturbed or } \\
\text { swollen }\end{array}$ \\
\hline
\end{tabular}

\begin{tabular}{|c|c|}
\hline Effects on vasculature & $\begin{array}{c}\text { PECAM1 } \\
\text { staining (\%) }\end{array}$ \\
\hline $\begin{array}{l}\text { Little vasculature, } \\
\text { no coelomic vessel }\end{array}$ & 10 \\
\hline $\begin{array}{l}\text { No vasculature dividing, } \\
\text { no coelomic vessel }\end{array}$ & 10 \\
\hline $\begin{array}{l}\text { Coelomic vessel, some } \\
\text { microvessels, but } \\
\text { reduced density }\end{array}$ & 58 \\
\hline $\begin{array}{l}\text { Weak coelomic vessel, } \\
\text { less dense vasculature }\end{array}$ & 54 \\
\hline
\end{tabular}

VEGFA, vascular endothelial growth factor A; KDR, kinase insert domain protein receptor; FLT1, FMS-like tyrosine kinase 1; NRP1, neuropilin 1; PI3K, phosphatidylinositol 3-kinase; PECAM1, platelet/endothelial cell adhesion molecule 1. 
mouse); in the tyrosine kinase domain: Y1054 and Y1059 (Y1053, Y1057 mouse); and in the C-terminal domain Y1175 and Y1214 (Y1173, Y1212 mouse) (Eliceiri et al. 1999, Werdich \& Penn 2005, Vieira et al. 2010). Most phosphorylation experiments have been conducted in endothelial cells; however, these tyrosine residues recruit different downstream signaling molecules when phosphorylated to induce different events (Eliceiri et al. 1999, Werdich \& Penn 2005, Vieira et al. 2010). This autophosphorylation is actually a form of trans-phosphorylation that is prevented until the conformation of KDR changes following VEGFA binding and the receptor monomers come into close juxtaposition (Tao et al. 2001).

KDR phosphotyrosines such as Y951 and Y1175 are recognized by SRC family kinases, which have been shown to modulate endothelial proliferation and migration (Eliceiri et al. 1999, Werdich \& Penn 2005, Vieira et al. 2010). Many different knockout mouse models have been developed that mutate or eliminate these tyrosine residues in order to determine their function (Fig. 3). The Y951 phosphotyrosine works through TSAd (T Cell-Specific Adapter) and Src and is involved in endothelial cell permeability and migration, while both Y1175 and Y1214 are also involved in endothelial cell proliferation or migration as indicated through mutation experiments (Rajagopal et al. 1999). The tyrosine residue Y1214 works through growth factor receptor bound protein 2 (GRB2) and has been implicated to be in control of actin reorganization and cell migration, which is thought to occur through CDC42 (cell division cycle 42) and MAPK (mitogen-activated protein kinase) cascades (Lamalice et al. 2004) (Fig. 3). Many different signal transduction pathways occur through Y1175: activation of phospholipase C (PLC) gamma, protein kinase C (PKC) and MAPK to cause proliferation. Src is recruited to this residue as well as SHB (src homology 2 domain-containing transforming protein B) which will allow for migration, survival and permeability of endothelial cells (Aouadi et al. 2006). SHB controls endothelial cell migration through focal adhesion kinase (FAK) in a PI3 (phosphoinositide-3) kinase-mediated pathway (Kriz et al. 2006) (Fig. 3). Caires et al. (2012) demonstrated that during early postnatal periods, the 1054 phosphotyrosine is autophosphorylated (1053 in the mouse), and VEGFA signaling through KDR is clearly present in both Sertoli, Leydig and germ cells at different stages of early postnatal development (Caires et al. 2012). Thus, these pathways should be explored to determine which phosphotyrosines are specifically necessary for VEGFA's function within the developing testis during sex-specific vascularization.
KDR is critical to embryogenesis, since KDR knockout mice die at E8.5-E9.5 (Shalaby et al. 1995). These embryos lack blood island formation in the yolk sac and experience a dramatic reduction in hematopoietic precursors, suggesting KDR is necessary for vasculogenesis. Furthermore, since they mark the early hemangioblast that differentiates into endothelial cells as well as hematopoietic progenitors, it is possible that KDR is also involved in hematopoiesis as well as vascularization of tissues through endothelial cells (Murray 1932, Jaffredo et al. 2005, Medvinsky et al. 2011, Ciau-Uitz et al. 2013). Interestingly, mice carrying only a single amino acid mutation that prevents KDR activation of ERK 1/2 die inutero due to vascular defects, suggesting that phosphorylation of this receptor is critical to multiple vasculature functions within the developing embryo (Sakurai et al. 2005).

\section{What is the expression pattern of the KDR, FLT1 receptors during testis development?}

Expression of KDR occurs relatively early and marks sexspecific vascular development in both the testis and ovary as indicated in KDR-LacZ transgenic mice (Bott et al. 2010). Expression of KDR is apparent in cells that appear to be migrating into the testis at the time of sex-specific migration. Later as seminiferous cords form and are apparent, these KDR-LacZ marked cells are present around the seminiferous cords (Bott et al. 2006, Bott et al. 2010). Since the KDR receptor signals through tyrosine kinase autophosphorylation, several different tyrosine kinase inhibitors were utilized to determine how this may affect seminiferous cord formation and sex-specific vascular development in testis organ cultures. In rat testis organ cultures, VEGFR-TKI (a tyrosine kinase inhibitor specific to KDR and FLT1) inhibited sex-specific vascular development (reduction by $90 \%$ in all vascular development in the testis; Table 1) and seminiferous cord formation (Bott et al. 2006). In addition, a KDR-specific inhibitor, SU1498, reduced vascular development by $90 \%$ and perturbed cord formation (Bott et al. 2006) (Table 1). Furthermore, KDRLacZ-positive staining in mouse testis organ cultures was reduced at day 1, 2 and 3 of culture by 66,90 and $99 \%$ respectively when they were treated with VEGFR-TKI. These data suggest that endothelial cell migration, proliferation and survival may have been blocked, which prevented the testis from being vascularized (Bott et al. 2010). Thus, it does appear that KDR-LacZ-marked cells migrate into the testis and can be inhibited by a specific VEGFR inhibitor. Other inhibitors to PI3 kinase have also

Published by Bioscientifica Ltd. 
been demonstrated to impair sex-specific vascular development but only reduce vascular development by 56\% (Bott et al. 2006) despite perturbing seminiferous cord formation (Uzumcu et al. 2002b, Bott et al. 2006) (Table 1). Inhibition of the MAPK pathway also alters cord formation (Uzumcu et al. 2002b), but vascular development was not evaluated. Since VEGFA signals through KDR to stimulate both MAPK and PI3 kinase, these data support evidence of a role for VEGFA in regulating sex-specific vascular development within the developing rodent testis.

FLT1, however, is not expressed in the rodent until after cord formation in the male (Bott et al. 2006), while both KDR and FLT1 are expressed early in the ovary (McFee et al. 2009). KDR, FLT1 and VEGFA are expressed by oocyte cysts, oocytes and pre-granulosa/granulosa cells of all stage follicles at P0, P3 and P10, as well as in theca cells of late antral follicles (McFee et al. 2009). There is a possibility that FLT1 expression in the ovary sequesters the VEGFA ligand and prevents it from binding to KDR and to block endothelial cell migration within the ovary at the time sex-specific vascular development occurs in the testis.

\section{What are the alternatively spliced products of VEGFA and what are their function(s)?}

Of the 25000 genes in the human genome, at least 70\% are alternatively spliced, and abnormal alternative splicing can be correlated with a large number of human genetic deficiencies (Black 2003, Matlin et al. 2005). VEGFA is transcribed from a single gene that is alternatively spliced into many different isoforms depending on the cell type of interest. Many VEGFA isoforms have been identified (VEGFA111, 121, 165, 148, 145, 183, 189, 206), and the most common VEGFA isoforms that have been studied are human angiogenic VEGFA206, VEGFA189, VEGFA165, VEGFA145 and VEGFA121 (Fig. 4). The numbers on the isoforms denote the number of amino acids, and in the rodent there is one less amino acid for each isoform: VEGFA205, VEGFA188, VEGFA164, VEGFA144, VEGFA120 (Fig. 4). For this review, we will utilize the rodent VEGFA isoforms, since much of the research discussed will be in the rodent (Hoeben et al. 2004, Giacca 2010, Kajdaniuk et al. 2011).

Within the Vegfa gene, there are eight exons, and all VEGFA isoforms contain exons 1-5 except for a newly identified isoform, VEGFA111, which contains only 1-4 and exon 8. A signal peptide is located within exons 1 and 2 and, upon cleavage, produces a mature peptide. In exon 5 , there are cleavage sites for plasmin and matrix metalloproteinases. Since VEGFA111 does not contain exon 5, this isoform is resistant to their cleavage and is a critical compound utilized in therapies for different cell ischemia (Houck et al. 1991, Mineur et al. 2007). Exons 6a and 7 encode heparin binding domains and isoforms containing these exons bind to cell surfaces and are not as diffusible as isoforms that do not contain these exons. Also contained within exons $6 \mathrm{a}$ and 7 are a neuropilin binding site (Keyt et al. 1996, Lee et al. 2005). The $5^{\prime}$ untranslated region (UTR) of Vegfa is $\sim 1038$ nucleotides in humans and consists of three CUG start codons, an AUG initiation codon and two internal ribosome entry sites (IRESes) that can control VEGFA translation. The $3^{\prime} \mathrm{UTR}$ consists of polyadenylation signals and AU-rich response element, which allows for response to stabilizing and destabilizing mRNAs (Konopatskaya et al. 2006, Seifi et al. 2012) (Fig. 4).

The VEGFA205 isoform contains all exons and is proposed to bind more tightly to extracellular matrix proteins in addition to being greater in amino acid number than other isoforms. The VEGFA188 isoform has two heparin binding domains, remains relatively close to the cell in which it was secreted, and acts locally to support branching of vasculature. The VEGFA164 isoform contains only one heparin-binding domain and has intermediate diffusibility, and has a prominent role in the formation of large blood vessels. The VEGFA120 isoforms lacks a heparin-binding domain, is the most diffusible and can migrate the farthest from the secreted cells. The differences in diffusibility of these different VEGFA isoforms allow for the development of a chemoattractant gradient that induces endothelial cells to migrate toward cells that produce VEGFA (Carmeliet \& Collen 1999, Veikkola \& Alitalo 1999, Grunstein et al. 2000, Simons 2007, Krilleke et al. 2009, Ferrara 2010).

\section{What is the expression and potential actions of VEGFA isoforms in the developing testis?}

The presence of multiple VEGFA isoforms differing in number of amino acids was identified in the developing rat testis: VEGFA120, 164 and 188 (Bott et al. 2006) (Fig. 4). Using a pan antibody to all VEGFA isoforms, it was demonstrated that the protein for the pan-VEGFA (which detects both angiogenic and antiangiogenic isoforms) was lower at E13 and increased by P4. Sertoli cells had the greatest abundance of pan-VEGFA expression around the time of cord formation (Bott et al. 2006).

It does not appear that a chemoattractant gradient for VEGFA exists in the ovary around the time of seminiferous cord formation in the rat testis, because the only VEGFA isoforms that are present are VEGFA164 and VEGFA120.

Published by Bioscientifica Ltd 
A

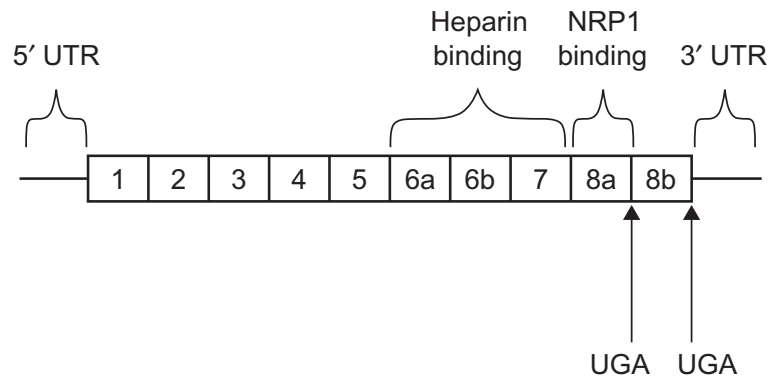

B

Rodent Vegfa gene

\section{Angiogenic VEGFA isoforms}

VEGFA205 \begin{tabular}{|l|l|l|l|l|}
\hline Exons 1-5 & $6 \mathrm{a}$ & $6 \mathrm{~b}$ & 7 & $8 \mathrm{a}$ \\
\hline
\end{tabular}

VEGFA188 \begin{tabular}{|l|l|l|}
\cline { 2 - 3 } Exons 1-5 & 7 & $8 \mathrm{a}$ \\
\hline
\end{tabular}

VEGFA164 \begin{tabular}{|l|l|l|l|}
\hline Exons 1-5 & $6 \mathrm{a}$ & 7 & $8 \mathrm{a}$ \\
\hline
\end{tabular}

VEGFA120 Exons 1-5 $8 \mathrm{a}$

C
Angiogenic VEGFA isoforms

\begin{tabular}{|c|c|c|c|c|c|c|}
\hline VEGFA205/206 & Exons 1-5 & $6 a$ & $6 b$ & 7 & & $8 a$ \\
\hline VEGFA188/189 & Exons $1-5$ & & 7 & $8 a$ & & \\
\hline VEGFA164/165 & Exons $1-5$ & $6 a$ & & & $8 a$ & \\
\hline VEGFA120/121 & Exons 1-5 & $8 a$ & & & & \\
\hline
\end{tabular}

Antiangiogenic VEGFA isoforms Alternative splicing substituting $8 \mathrm{a}$ for $8 \mathrm{~b}$ exon

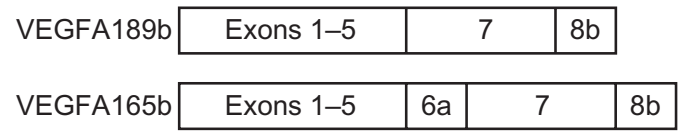

VEGFA121b Exons 1-5 $8 \mathrm{~b}$

C

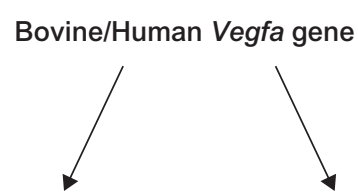

Antiangiogenic VEGFA isoforms

Alternative splicing substituting $8 \mathrm{a}$ for $8 \mathrm{~b}$ exon

\begin{tabular}{|c|c|c|c|c|c|}
\hline VEGFA204b/205b & Exons 1-5 & $6 a$ & $6 b$ & & \\
\hline VEGFA188b/189b & Exons $1-5$ & & 7 & 8 & \\
\hline VEGFA164b/165b & Exons 1-5 & $6 a$ & & & $8 b$ \\
\hline VEGFA120b/121b & Exons $1-5$ & $8 b$ & & & \\
\hline
\end{tabular}

Programmed translational readthrough

VEGFAx

\begin{tabular}{|l|l|l|l|l|l|l|}
\hline Exons $1-5$ & $6 \mathrm{a}$ & $6 \mathrm{~b}$ & 7 & $8 \mathrm{a}$ & $\mathrm{Ax}$ & $8 \mathrm{~b}$ \\
\hline
\end{tabular}

\section{Figure 4}

VEGFA gene containing all exons and both heparin- and NRP1-binding sites as well as the canonical stop codons targeted for alternative splicing between either angiogenic or antiangiogenic isoforms ( $A$ ). Various rodent angiogenic VEGFA isoforms ( $B$, left) and antiangiogenic isoforms ( $B$, right) have been identified following alternative splicing. In the human and

The two higher-molecular-weight VEGFA isoforms VEGFA188 and VEGFA205 have not been detected (McFee et al. 2009); thus, we hypothesize that there is no viable chemoattractant gradient to allow for endothelial cell migration from the mesonephros into the ovary. bovine, the amino acids numbers differ from those found in the rodent. Pictured are the most well-known/studied angiogenic VEGFA isoforms (left, C) and antiangiogenic isoforms (top right, C). Also depicted is the recently identified VEGFAx that possesses antiangiogenic properties in humans and bovines (bottom right, C).

Furthermore, treatment of E13 rat testis organ cultures with VEGFA120 and VEGFA164 causes formation of altered (absent, swollen and misshaped) seminiferous cords as well as dramatically increased vascular density (160 and $157 \%$ that of controls; Table 2). Thus, excess

Published by Bioscientifica Ltd. 
Table 2 Effects of recombinant VEGFA protein or VEGFAxxxb antibody on Rat embrynic testis cord formation and vascular development in vitro (data from Baltes-Breitwisch et al. (2010))

Recombinant VEGFA protein
VEGFA120
VEGFA164
VEGFAxxxb antibody
( $5 \mathrm{ng} / \mathrm{ml})$
VEGFAxxxb antibody
$(50 \mathrm{ng} / \mathrm{ml})$

Effects on vasculature
Thickened coelomic vessel, more
vasculature between cords
Thickened coelomic vessel, more
vasculature between cords that
formed
Increased vasculature all
throughout testis
Increased vasculature all
throughout testis

PECAM staining (\%) 157

160

195

195

VEGFA, vascular endothelial growth factor A.

VEGFA angiogenic isoforms 164 and 120 can elicit detrimental effects on testis development and potentially have as dramatic effects as inhibition of VEGFA signal transduction discussed earlier (Bott et al. 2006) (Table 1). All of these VEGFA angiogenic isoforms have been shown to bind both KDR and NRP1, but even though there may be binding of VEGFA120 (which does not have a heparin and thus NRP1-binding domain) to NRP-1, the bridging to KDR does not appear to occur. This may affect the amplification of the VEGFA120 signal transduction as well as the recycling of the KDR receptor within the cell (Pan et al. 2007).

\section{VEGFA antiangiogenic isoforms}

In 2002, a second set of sister isoforms was identified through alternative splicing and replacement of exon $8 \mathrm{a}$ with 8b (Bates et al. 2002) (Fig. 4). These sister VEGFA isoforms were considered inhibitory to angiogenic functions and were labeled antiangiogenic VEGFA isoforms. Several antiangiogenic isoforms have been identified: VEGFA212b, VEGFA145b, 183b, 189b, 165b and 121b (Bates et al. 2002, Woolard et al. 2004, Dehghanian et al. 2014) (Fig. 3). VEGF165b is normally expressed in tissues but is downregulated in prostate and renal tumors, suggesting a role in inhibiting the vasculogenic and angiogenic actions of other VEGF isoforms (Bates et al. 2002, Woolard et al. 2004). Several reports have suggested that these antiangiogenic VEGFA isoforms may function to antagonize angiogenic VEGFA isoform functions through binding of the receptors and preventing angiogenic isoforms from binding (Qiu et al. 2009).

Much controversy has ensued over whether these ' $b$ ' isoforms exist or whether they are artifacts of alternative splicing (Harris et al. 2012). While it is true that determining the difference in the angiogenic vs the antiangiogenic isoforms has been a challenge, data from our laboratory and others using either recombinant angiogenic or antiangiogenic VEGFA isoforms has resulted in very different outcomes that demonstrate the existence of divergent VEGFA isoforms (Artac et al. 2009, McFee et al. 2009, Baltes-Breitwisch et al. 2010, Caires et al. 2012, Bates et al. 2013).

For instance, the VEGFAxxxb antibody (detects all antiangiogenic isoforms but sold as antiVEGFA165b) detected antiangiogenic isoforms in germ cells from E14 to E16 with expression in the interstitium by P0 (Baltes-Breitwisch et al. 2010). This result in expression was very different from the panVEGFA antibody, which detects all VEGFA isoforms where expression was detected in Sertoli cells and potentially some germ and Leydig cells (Bott et al. 2006). When we used this antibody to the exon $8 \mathrm{~b}$ (which will neutralize antiangiogenic isoforms and allow endogenous VEGFA angiogenic isoforms to bind) on E13 rat testis organ cultures we had similar results as treating with recombinant VEGFA120 or VEGFA164 (Table 2). Either dose of VEGFAxxxb antibody, dramatically increased vascular density (195\%) versus control testes compared to increases in vascular density of $160 \%$ (VEGFA164) or 157\% (VEGFA120) (Table 2). In addition, the seminiferous cords were swollen, perturbed, or misshapen, which was very similar to what was seen with the recombinant angiogenic VEGFA isoforms treatment (Baltes-Breitwisch et al. 2010). Thus, it appears that the removal of the antiangiogenic isoforms increases the amount of endogenous angiogenic VEGFA isoforms that can bind to the VEGFA receptors and elicit similar effects to treatments with recombinant angiogenic VEGFA isoforms. Thus, from our data and others we would suggest that the antiangiogenic isoforms do exist, whether they are produced from alternative splicing or through other recently identified means.

Published by Bioscientifica Ltd. 
Whole testis western blots conducted with the antiangiogenic VEGFAxxxb antibody did not demonstrate major differences in the levels of antiangiogenic VEGFA isoform abundance during early testis development, but the immunohistochemistry clearly indicated that VEGFAxxxb isoforms were not expressed in somatic cells and only in germ cells during early testis development (Baltes-Breitwisch et al. 2010). Quantitative PCR demonstrated a fivefold greater abundance of antiangiogenic VEGFA165b in the ovary vs the testis at E13, which indicated that antiangiogenic isoforms may be inhibiting angiogenic VEGFA isoform functions related to endothelial cell migration or development of chemoattractant gradients.

Recently, a paper was published in Cell (Eswarappa et al. 2014) that identified yet another antiangiogenic VEGFA isoform in human and bovine endothelial cell lines that is produced by programmed translational readthrough, which has a cis-acting element in the Vegfa $3^{\prime}$ UTR that serves a dual function (Fig. 4). It can encode the shortened peptide but can also direct the programmed readthrough by decoding the UGA stop codon (Fig. 4). A heterogeneous nuclear ribonucleoprotein (hnRNP) A2/B1 binds this element and promotes readthrough, producing a product that has exon $8 \mathrm{a}$ and $8 \mathrm{~b}$. This product acts similarly to antiangiogenic isoforms and is downregulated in certain cancers (Eswarappa et al. 2014). The authors of this paper have named this isoform VEGFAx. The Ax is named for the Ax element, which is a 62-nucleotide extension inserted between the two stop codons that normally would confer either angiogenic (with exon 8a) or antiangiogenic isoforms (with exon 8b; Fig. 4). Thus, the binding protein hnRNP A2/B1 binds the A2/B1 response element (A2RE) in the Ax element and positively regulates VEGFA readthrough. This finding is exciting, since this is the first time that a trans factor has been identified that regulates translational readthrough. Furthermore, most translational readthrough was only thought to occur in evolutionarily lower-ordered species such as Drosophila, viruses, etc. Since the VEGFAx protein acts like an antiangiogenic isoform, more experiments are needed to determine if this protein is present only in certain cell types that produce this trans-factor hnRNP A2/B1 or whether they are ubiquitous (Eswarappa et al. 2014).

In experiments where VEGFA isoforms have been subcloned from primary bovine granulosa cells, some VEGFA isoform PCR sub-cloned products contained both exon $8 \mathrm{a}$ and $8 \mathrm{~b}$ suggesting that there is a readthrough product in the bovine (McFee, Spuri Gomes, Artac, Summers, Pohlmeier, Brauer, Kurz, Cushman, Wood and Cupp, unpublished observations) (Fig. 4). This was not the case for sub-cloned VEGFA from rat granulosa or Sertoli cells. In addition, there were sub-cloned products that only contained either the $8 \mathrm{a}$ or $8 \mathrm{~b}$ in the bovine and rat without the Ax product. Thus, within each cell, the necessary machinery - whether it is splicing proteins or proteins that allow for programmed read through - may be present at critical physiological states to ensure the appropriate balance of VEGFA angiogenic and antiangiogenic isoforms. More experiments are needed to ensure the VEGFAx product exists; however, if these data are confirmed, there could be an evolutionary change in insertion of the Ax sequence (62 nucleotides) that may provide different functions in higher evolved mammals.

\section{Are there differences in VEGFA angiogenic and antiangiogenic isoform actions on their receptors?}

Neuropilin 1 (NRP1) was originally identified as a receptor in the nervous system and was found to modulate semaphorin signals (He \& Tessier-Lavigne 1997, Takahashi et al. 1998) and direct neuronal axon guidance. However, NRP1 has also been found to be critical for vascular development in cooperation with the VEGFA angiogenic isoforms in many different angiogenic processes (Kawasaki et al. 1999). NRP1 knockout mice die between 10.5 and 12.5 and have vasculature development defects as well as heart and neural defects suggesting that NRP1 is critical for both vascular and neuronal development (Kawasaki et al. 1999). NRP1 can bind to semaphorins instead of VEGFA, and this impairs endothelial cell migration (Miao et al. 1999). Semaphorins are present within the testis and appear to be secreted by Sertoli cells (Perala et al. 2005). Whether semaphorins are antagonistic to vascular development within the testis is still unknown. Alternatively, NRP/VEGFA complexes binding to FLT1 can also prevent endothelial cell migration and vascular development (Miao et al. 1999), so there are potentially many checkpoints present within the testis to prevent over-vascularization to ensure development of the seminiferous cords.

NRP1 is a co-receptor to VEGFA but it does not bind either KDR or FLT1 but instead binds to a region on the VEGFA ligand (Fig. 4). Because KDR lacks a PDZ-binding domain it cannot interact with a PDZ protein synectin (which is also called GIPC1 or NIP). NRP1 has a SEA motif, which allows for PDZ protein synectin binding. KDR can utilize NRP1 bound to VEGFA angiogenic isoforms as a bridge to enhance signal transduction and also allow for

Published by Bioscientifica Ltd 
appropriate trafficking of NRP1 within the cell to allow for receptor recycling (Cai \& Reed 1999, Wang et al. 2006).

Due to the presence of exon $8 \mathrm{~b}$ rather than $8 \mathrm{a}$, the VEGFA antiangiogenic isoforms cannot bind NRP1, since much of their binding region is within the exon 8a region. Thus, elimination of NRP1 or overexpression will only affect angiogenic VEGFA isoform functions (Kawamura et al. 2008). When NRP1 is bound to VEGFA164 and then bound and signaled through KDR, it causes the KDR receptor to be recycled through Rab5, Rab4 and Rab11 vesicles. However, antiangiogenic VEGFA cannot bind NRP1. Therefore, when VEGFA164b binds to KDR, KDR bypasses the Rab11 vesicles in cells and is routed to the Rab7 vesicles, which moves KDR to the degradation pathway. Also, if the SEA-binding motif for synectin is deleted from NRP1, this will attenuate the receptor-ligand signal amplification since the SEA carboxy-terminal domain of NRP1 mediates the events to allow for KDR recycling via Rab11 positive endosomes (Ballmer-Hofer et al. 2011).

\section{How are NRP1 receptors expressed and regulated within the gonad?}

NRP1 receptors are present early in both the testis and ovary (Walker, Lu, Clopton, and Cupp, unpublished observations) and have the potential to interact with VEGFA and present both to KDR and FLT1. Because FLT1 is present during gonadal development, it is possible that FLT1 is sequestering NRP1 and VEGFA away from KDR and limiting signal transduction and subsequent endothelial cell migration in the ovary (Baltes-Breitwisch et al. 2010). An inhibitor to the NRP1 co-receptor, Je-11, was utilized to determine its effects on E13 rat testis organ cultures. Initially, this inhibitor was thought to be specific only to KDR but later was found to inhibit only NRP1. This inhibitor caused a $42 \%$ reduction in vascular development with a less defined coelomic vessel and cords that were either not present or perturbed (Bott et al. 2006) (Table 1). This inhibitor was not as effective as the inhibitors either to KDR alone or to KDR and FLT1 simultaneously, suggesting that KDR can signal and cause vascular development independent of NRP1, which has been demonstrated in many different endothelial cells and systems with vascularization (Vieira et al. 2010). However, these results do demonstrate its role in enhancement of KDR signaling. Through altered receptor recycling, we can envision a function for NRP1 in development of endothelial cell migration, arteriogenesis - mainly the coelomic vessel - and induction of cord formation within the developing testis.

\section{What happens in vivo when VEGFA isoforms are eliminated in somatic and germ cells during testis development?}

In order to determine whether VEGFA was critical for testis development, multiple conditional knockout mouse lines were developed to eliminate all VEGFA isoforms in Sertoli and some germ cells ( $p$ Dmrt1-Cre; Vegfa ${ }^{-1-}$ ), Sertoli and Leydig cells (Amhr2-Cre; $\left.\mathrm{Vegfa}^{-/}\right)$, and Sertoli cells only (Amh-Cre; $\mathrm{Vegfa}^{-/-}$and Sry-Cre; $\mathrm{Vegfa}^{-/-}$). To date, testes formed normally in these male mice by $\mathrm{P} 0$, and there do not appear to be differences in vasculature based on published work from our laboratory (Lu et al. 2013) as well as on unpublished results (Sargent, Spuri Gomes, Essink, Kurz, Pohlmeier, Ferrara, Bouma, McLean, and Cupp; Sargent, Essink, Bremer, Pohlmeier, and Cupp, unpublished observations) in VEGFA or NRP1 knockout versus the control testes. Instead of effects on vasculature, our laboratory has demonstrated effects on male fertility through altered spermatogonial stem cell maintenance (Lu et al. 2013). Furthermore, using different VEGFA angiogenic and antiangiogenic isoforms, we have also demonstrated different effects on the number of spermatogonial stem cells in endogenously depleted recipients (Caires et al. 2012). It is possible that vascular development in these males is delayed embryonically; however, what we can state is that VEGFA does not appear to be required for testis development, since these testes contain a coelomic vessel and seminiferous cords that form into seminiferous tubules. Furthermore, from the P0 time period, the only phenotype that appears to be abnormal is the number of germ cells at different stages and the number of undifferentiated spermatogonia leading to differences in number of sperm (Lu et al. 2013). These findings were echoed by measurement of VEGFA in roe deer, where expression correlated more with the transition of germ cell stages than with testis microvasculature (Wagener et al. 2010). When Vegfa was in control of and overexpressed by the MMTV promoter in mice, the animals were infertile. This infertility was thought to result, in part, from testicular spermatogenic cell arrest, which further demonstrates non-endothelial effects of VEGFA in the testis (Korpelainen et al. 1998).

Due to our conditional knockout mouse data, it does not appear that VEGFA is absolutely required for normal testis development. In many ways, this makes sense, because throughout testis development there are multiple factors that upregulate expression of genes to ensure proper differentiation of a testis. NR5A1 induces initial expression of Sox9, which is then upregulated by SRY and

Published by Bioscientifica Ltd. 
SOX9 (Sekido \& Lovell-Badge 2008), and SOX9 not only upregulates FGF9 and PTGS but also upregulates itself (DiTacchio et al. 2012). One role of both PTGS and FGF9 is to continually provide sustained expression of SOX9 (Rossitto et al. 2015) (Fig. 1). Thus, since sex-specific vascular development drives seminiferous cord formation, it would logically follow that there are multiple mechanism that allow for this to happen, potentially in the absence of one, such as VEGFA.

\section{What are some potential alternative pathways to initiate endothelial cell migration and sex-specific vascularization that do not utilize VEGFA?}

\section{Cox1/2 pathway}

VEGFA is regulated through increased hypoxia inducible factor 1, alpha subunit (HIF1A) upregulation during hypoxia. It is possible that the COX pathway through PGE2 upregulates VEGFA as well as direct upregulation through COX2 (Fig. 2). Postnatal day 30 whole testes were collected from Sry-Cre; $\mathrm{Vegfa}^{-/-}$conditional knockout mice and compared to controls for differences in genes within the VEGFA signal transduction pathway using a VEGFA signal transduction array plate. When the data were analyzed with Ingenuity Pathway Analysis (IPA), the COX1 (PTGS1) constitutively expressed gene was upregulated fivefold (Sargent KM, Spuri Gomes R, Essink JR, Kurz SG, Pohlmeier WE, Ferrara N, Bouma GJ, McLean DJ, and Cupp AS; Sargent KM, Bremer ML, Pohlmeier WE and Cupp AS, unpublished observations). These data indicate that the elimination of VEGFA (in this case in Sertoli cells) may allow for compensatory mechanisms that regulate other angiogenic factors to allow for normal tissue development.

\section{Other VEGF ligands}

VEGFB knockout mice are fertile and viable with no apparent phenotype; however, they do exhibit a subtle cardiac phenotype (Aase et al. 1999). Transcription of the $V e g f b$ gene is not stimulated by hypoxia or other growth factors, cytokines, etc. VEGFB binds to FLT1 and NRP1, while VEGFC binds to VEGFR3 and KDR and enhances vasculature within the lymphatic system. VEGFC is expressed in the heart, placenta, ovary, small intestine and thyroid gland (Olofsson et al. 1999). In the embryo, it is expressed in regions where lymphatic vessels sprout from embryonic veins. Similar to VEGFB, this gene is not regulated by hypoxia but interleukin 1 (IL1) and tumor necrosis factor (TNF) can increase VEGFC (Kukk et al. 1996). VEGFD is expressed in the lung, heart, skeletal muscle, colon and small intestine. In embryos, VEGFD is most abundant in the lung. Like VEGFC, it binds to both VEGFR3 and KDR (Olofsson et al. 1999). There have been no reports of VEGFB or VEGFC present in or involved with testis development, but due to their potential actions through VEGF receptors, these could be two potential candidates that may function in VEGFA's absence to initiate sex-specific vascular development.

\section{What about other growth factors that have similar functions to VEGFA that could compensate for sex-specific vascular development?}

\section{Platelet-derived growth factor}

Platelet-derived growth factor receptor alpha (PDGFR $\alpha$ ) and PDGFR $\beta$ are receptors for PDGF-AA, PDGF-BB, PDGFCC and PDGF-DD and are structurally similar to VEGFRs receptors (Heldin 2013). PDGFB is expressed in endothelial cells and $P d g f b$ and Pdgfrb knockout mice are embryonic lethal during late gestation due to widespread hemorrhaging and capillary dilation (Leveen et al. 1994, Soriano 1994, Lindahl et al. 1997, Hellstrom et al. 1999). Fetuses appear normal, but the absence of vascular smooth muscle cells and/or pericytes leads to cardiovascular complications. In the rat, PDGF-AA, PDGF-BB and their receptors are expressed in human fetuses (Basciani et al. 2002), and PDGF-BB, when inhibited, has been demonstrated to affect vascular development and perturb or totally inhibit seminiferous cord formation in the mouse (Puglianiello et al. 2004). Inhibitors to the PDGF-BB signal transduction pathway (PGFR-specific inhibitor Tyrophostin) have also inhibited seminiferous cord formation in the rat (Uzumcu et al. 2002a). Furthermore, PDGF has also been identified to work cooperatively with VEGFA in vascular events and remodeling within the testis (Cool et al. 2011) during the process of sex-specific vascular development. Thus, PDGF and its receptors may comprise a mechanism where endothelial migration and seminiferous cord formation occur in the absence of VEGFA isoforms.

\section{R-spondin homolog}

Recently, RSPO1 (R-spondin homolog), which is necessary for ovarian development, has been shown to induce angiogenesis within the developing testis and to inhibit

Published by Bioscientifica Ltd 
actions of the dickkopf homolog 1 (Dkk1) gene, which perturbs endothelial branching by inhibiting PDGFB (Caruso et al. 2015). Interestingly, RSPO1 can rescue DKK1 inhibition of angiogenesis, indicating that perhaps RSPO1 is critical for necessary availability of PDGFB for endothelial cell branching during testis development. These actions of RSPO1 are thought to be mediated through beta catenin (CTNNB1), since testes treated in vitro with RSPO1 exhibit enhanced nuclear translocation of CTNNB1, which will affect gene expression within the nucleus (Caruso et al. 2015).

\section{VEGF receptors that bind other ligands}

It is possible that the receptors that VEGFA signals through may elicit effects following binding by other ligands within the VEGF family to induce endothelial cell migration. An example of this is the potential for FLT1 to be induced through hypoxia and cooperate with PGF (placental growth factor to promote pathological angiogenesis that occurs during diseases and disorder such as pre-eclampsia (Hiratsuka et al. 2001, Autiero et al. 2003). FLT1 upregulation can be stimulated by hypoxia (Gerber et al. 1997) and has been shown to activate PGF in VEGFresponsive monocytes that release proangiogenic factors. Further, FLT1 tyrosine kinase signaling mediates chemotactive macrophage migration in response to PGF and both VEGF, and PGF promotes macrophage survival during tumor angiogenesis (Barleon et al. 1996, Clauss et al. 1996, Hiratsuka et al. 1998, Adini et al. 2002, Selvaraj et al. 2003). Recently, macrophage migration was demonstrated to occur during testis development and the authors implicated that VEGFA was expressed by macrophages and that vascular development may thus be directed by these macrophages (DeFalco et al. 2014). These are intriguing data and may suggest that macrophages derived from the yolk sac (which are extraembryonic along with primordial germ cells) are critical for sex-specific vascular development. So the possibility of macrophages directing endothelial cell migration is a potential mechanism that should be further evaluated.

\section{Summary}

While there is overwhelming in vitro evidence to support the theory that VEGFA and its receptors, FLT1, KDR and NRP1, are critical for sex-specific vascular development that can allow for seminiferous cord formation, conditional knockout data in mice where VEGFA was eliminated in Sertoli, Leydig and germ cells do not support this theory. Because the development of the testis is so critical to the propagation of the species, suggesting that VEGFA can only be the critical regulator of this process may be somewhat simplistic. Just as SOX9 has multiple regulators that sustain its expression, there are potentially many independent angiogenic pathways that contribute to the migration of endothelial cells to initiate seminiferous cord formation. In this review article, we have suggested several other pathways that may independently mimic the actions of VEGFA in supporting endothelial cell migration and development of this quite extraordinary vascular development within the testis. We, along with others investigating this area will have many more years to work on unraveling the complexities of this pathway, to gain a better understanding of how the testis develops, and paving new avenues for treating infertility, which may be a predictor of male health and lifespan.

\section{Declaration of interest}

The authors declare that there is no conflict of interest that could be perceived as prejudicing the impartiality of this review.

\section{Funding}

This work was supported by grants from the National Institutes of Health/National Institute of Child Health and Human Development (NIH/NICHD; (HD41546, HD045250 and HD051979), and the Nebraska Department of Health and Human Services (NDHHS) Stem Cell Grant $(2012,2015)$.

\section{References}

Aase K, Lymboussaki A, Kaipainen A, Olofsson B, Alitalo K \& Eriksson U 1999 Localization of VEGF-B in the mouse embryo suggests a paracrine role of the growth factor in the developing vasculature. Developmental Dynamics 215 12-25. (doi:10.1002/(SICI)1097-

0177(199905)215:1\%3C;12::AID-DVDY3\%3E;3.0.CO;2-N)

Adams IR \& McLaren A 2002 Sexually dimorphic development of mouse primordial germ cells: switching from oogenesis to spermatogenesis. Development 129 1155-1164.

Adini A, Kornaga T, Firoozbakht F \& Benjamin LE 2002 Placental growth factor is a survival factor for tumor endothelial cells and macrophages. Cancer Research 62 2749-2752.

Albrecht KH, Capel B, Washburn LL \& Eicher EM 2000 Defective mesonephric cell migration is associated with abnormal testis cord development in C57BL/6J XY(Mus domesticus) mice. Developmental Biology 225 26-36. (doi:10.1006/dbio.2000.9819)

Aouadi M, Binetruy B, Caron L, Le Marchand-Brustel Y \& Bost F 2006 Role of MAPKs in development and differentiation: lessons from knockout mice. Biochimie 88 1091-1098. (doi:10.1016/j.biochi.2006.06.003)

Artac RA, McFee RM, Smith RA, Baltes-Breitwisch MM, Clopton DT \& Cupp AS 2009 Neutralization of vascular endothelial growth factor antiangiogenic isoforms is more effective than treatment with proangiogenic isoforms in stimulating vascular development and follicle progression in the perinatal rat ovary. Biology of Reproduction $\mathbf{8 1}$ 978-988. (doi:10.1095/biolreprod.109.078097) 
Autiero M, Luttun A, Tjwa M \& Carmeliet P 2003 Placental growth factor and its receptor, vascular endothelial growth factor receptor-1: novel targets for stimulation of ischemic tissue revascularization and inhibition of angiogenic and inflammatory disorders. Journal of Thrombosis and Haemostasis 1 1356-1370. (doi:10.1046/j.1538-7836. 2003.00263.x)

Bagheri-Fam S, Sim H, Bernard P, Jayakody I, Taketo MM, Scherer G \& Harley VR 2008 Loss of Fgfr2 leads to partial XY sex reversal. Developmental Biology 314 71-83. (doi:10.1016/j.ydbio.2007.11.010)

Ballmer-Hofer K, Andersson AE, Ratcliffe LE \& Berger P 2011 Neuropilin-1 promotes VEGFR-2 trafficking through Rab11 vesicles thereby specifying signal output. Blood 118 816-826. (doi:10.1182/blood-2011-01328773)

Baltes-Breitwisch MM, Artac RA, Bott RC, McFee RM, Kerl JG, Clopton DT \& Cupp AS 2010 Neutralization of vascular endothelial growth factor antiangiogenic isoforms or administration of proangiogenic isoforms stimulates vascular development in the rat testis. Reproduction 140 319-329. (doi:10.1530/REP-09-0456)

Barleon B, Sozzani S, Zhou D, Weich HA, Mantovani A \& Marme D 1996 Migration of human monocytes in response to vascular endothelial growth factor (VEGF) is mediated via the VEGF receptor flt-1. Blood $\mathbf{8 7}$ 3336-3343.

Basciani S, Mariani S, Arizzi M, Ulisse S, Rucci N, Jannini EA, Della Rocca C, Manicone A, Carani C, Spera G et al. 2002 Expression of platelet-derived growth factor-A (PDGF-A), PDGF-B, and PDGF receptor- $\alpha$ and $-\beta$ during human testicular development and disease. Journal of Clinical Endocrinology and Metabolism 87 2310-2319.

Bates DO, Cui TG, Doughty JM, Winkler M, Sugiono M, Shields JD, Peat D, Gillatt D \& Harper SJ 2002 VEGF165b, an inhibitory splice variant of vascular endothelial growth factor, is down-regulated in renal cell carcinoma. Cancer Research 62 4123-4131.

Bates DO, Mavrou A, Qiu Y, Carter JG, Hamdollah-Zadeh M, Barratt S, Gammons MV, Millar AB, Salmon AH, Oltean S et al. 2013 Detection of VEGF-A(xxx)b isoforms in human tissues. PLoS ONE 8 e68399. (doi:10.1371/journal.pone.0068399)

Black DL 2003 Mechanisms of alternative pre-messenger RNA splicing. Annual Review of Biochemistry 72 291-336. (doi:10.1146/annurev. biochem.72.121801.161720)

Bott RC, McFee RM, Clopton DT, Toombs C \& Cupp AS 2006 Vascular endothelial growth factor and kinase domain region receptor are involved in both seminiferous cord formation and vascular development during testis morphogenesis in the rat. Biology of Reproduction $\mathbf{7 5}$ 56-67. (doi:10.1095/biolreprod.105.047225)

Bott RC, Clopton DT, Fuller AM, McFee RM, Lu N \& Cupp AS 2010 KDRLacZ-expressing cells are involved in ovarian and testis-specific vascular development, suggesting a role for VEGFA in the regulation of this vasculature. Cell and Tissue Research 342 117-130. (doi:10.1007/ s00441-010-1038-9)

Buehr M, Gu S \& McLaren A 1993 Mesonephric contribution to testis differentiation in the fetal mouse. Development 117 273-281.

Burgoyne PS, Thornhill AR, Boudrean SK, Darling SM, Bishop CE \& Evans EP 1995 The genetic basis of XX-XY differences present before gonadal sex differentiation in the mouse. Philosophical Transactions of the Royal Society of London. Series B, Biological Sciences 350 253-260. discussion 260-251. (doi:10.1098/rstb.1995.0159)

Cai H \& Reed RR 1999 Cloning and characterization of neuropilin-1interacting protein: a PSD-95/Dlg/ZO-1 domain-containing protein that interacts with the cytoplasmic domain of neuropilin-1. Journal of Neuroscience 19 6519-6527.

Caires KC, de Avila JM, Cupp AS \& McLean DJ 2012 VEGFA family isoforms regulate spermatogonial stem cell homeostasis in vivo. Endocrinology 153 887-900. (doi:10.1210/en.2011-1323)

Carlsen E, Giwercman A, Keiding N \& Skakkebaek NE 1992 Evidence for decreasing quality of semen during past 50 years. BMJ 305 609-613. (doi:10.1136/bmj.305.6854.609)
Carlsen E, Giwercman A, Skakkabaek NE \& Keiding N 1993 Decreasing quality of semen. BMJ 306 461. (doi:10.1136/bmj.306.6875.461-b)

Carlsen E, Giwercman A, Keiding N \& Skakkebaek NE 1995 Declining semen quality and increasing incidence of testicular cancer: is there a common cause? Environmental Health Perspectives 103 137-139. (doi:10.1289/ehp.95103s7137)

Carmeliet P \& Collen D 1999 Role of vascular endothelial growth factor and vascular endothelial growth factor receptors in vascular development. Current Topics in Microbiology and Immunology 237 133-158.

Caruso M, Ferranti F, CoranoScheri K, Dobrowolny G, Ciccarone F, Grammatico P \& Catizone AG 2015 R-spondin 1/dickkopf-1/ $\beta$-catenin machinery is involved in testicular embryonic angiogenesis. PLOS ONE 10 e0124213. (doi:10.1371/journal.pone.0124213)

Cheng T, Cao W, Wen R, Steinberg RH \& LaVail MM 1998 Prostaglandin E2 induces vascular endothelial growth factor and basic fibroblast growth factor mRNA expression in cultured rat Muller cells. Investigative Ophthalmology \& Visual Science 39 581-591.

Chou MT, Wang J \& Fujita DJ 2002 Src kinase becomes preferentially associated with the VEGFR, KDR/Flk-1, following VEGF stimulation of vascular endothelial cells. BMC Biochemistry 3 32. (doi:10.1186/14712091-3-32)

Ciau-Uitz A, Pinheiro P, Kirmizitas A, Zuo J \& Patient R 2013 VEGFAdependent and -independent pathways synergise to drive $\mathrm{Scl}$ expression and initiate programming of the blood stem cell lineage in Xenopus. Development 140 2632-2642. (doi:10.1242/dev.090829)

Clauss M, Weich H, Breier G, Knies U, Rockl W, Waltenberger J \& Risau W 1996 The vascular endothelial growth factor receptor Flt-1 mediates biological activities. Implications for a functional role of placenta growth factor in monocyte activation and chemotaxis. Journal of Biological Chemistry 271 17629-17634. (doi:10.1074/jbc.271.30.17629)

Colvin JS, Green RP, Schmahl J, Capel B \& Ornitz DM 2001 Male-to-female sex reversal in mice lacking fibroblast growth factor 9. Cell $\mathbf{1 0 4}$ 875-889. (doi:10.1016/S0092-8674(01)00284-7)

Combes AN, Wilhelm D, Davidson T, Dejana E, Harley V, Sinclair A \& Koopman P 2009 Endothelial cell migration directs testis cord formation. Developmental Biology 326 112-120. (doi:10.1016/j.ydbio. 2008.10.040)

Cool J, Carmona FD, Szucsik JC \& Capel B 2008 Peritubular myoid cells are not the migrating population required for testis cord formation in the XY gonad. Sexual Development 2 128-133. (doi:10.1159/000143430)

Cool J, DeFalco TJ \& Capel B 2011 Vascular-mesenchymal cross-talk through Vegf and Pdgf drives organ patterning. PNAS 108 167-172. (doi:10.1073/pnas.1010299108)

Cunningham SA, Tran TM, Arrate MP \& Brock TA 1999 Characterization of vascular endothelial cell growth factor interactions with the kinase insert domain-containing receptor tyrosine kinase. A real time kinetic study. Journal of Biological Chemistry 274 18421-18427. (doi:10.1074/ jbc.274.26.18421)

Cupp AS, Tessarollo L \& Skinner MK 2002 Testis developmental phenotypes in neurotropin receptor trkA and trkC null mutations: role in formation of seminiferous cords and germ cell survival. Biology of Reproduction 66 1838-1845. (doi:10.1095/biolreprod66.6.1838)

Cupp AS, Uzumcu M \& Skinner MK 2003 Chemotactic role of neurotropin 3 in the embryonic testis that facilitates male sex determination. Biology of Reproduction 68 2033-2037. (doi:10.1095/biolreprod.102.012617)

Daneau I, Ethier JF, Lussier JG \& Silversides DW 1996 Porcine SRY gene locus and genital ridge expression. Biology of Reproduction 55 47-53. (doi:10.1095/biolreprod55.1.47)

Davis-Smyth T, Presta LG \& Ferrara N 1998 Mapping the charged residues in the second immunoglobulin-like domain of the vascular endothelial growth factor/placenta growth factor receptor Flt-1 required for binding and structural stability. Journal of Biological Chemistry $\mathbf{2 7 3}$ 3216-3222. (doi:10.1074/jbc.273.6.3216)

DeFalco T, Bhattacharya I, Williams AV, Sams DM \& Capel B 2014 Yolk-sacderived macrophages regulate fetal testis vascularization and morphogenesis. PNAS 111 E2384-E2393. (doi:10.1073/pnas.1400057111) 
Dehghanian F, Hojati Z \& Kay M 2014 New insights into VEGF-A alternative splicing: key regulatory switching in the pathological process. Avicenna Journal of Medical Biotechnology 6 192-199.

DiTacchio L, Bowles J, Shin S, Lim DS, Koopman P \& Janknecht R 2012 Transcription factors ER71/ETV2 and SOX9 participate in a positive feedback loop in fetal and adult mouse testis. Journal of Biological Chemistry 287 23657-23666. (doi:10.1074/jbc.M111.320101)

Eliceiri BP, Paul R, Schwartzberg PL, Hood JD, Leng J \& Cheresh DA 1999 Selective requirement for Src kinases during VEGF-induced angiogenesis and vascular permeability. Molecular Cell 4 915-924. (doi:10.1016/ S1097-2765(00)80221-X)

Eswarappa SM, Potdar AA, Koch WJ, Fan Y, Vasu K, Lindner D, Willard B, Graham LM, DiCorleto PE \& Fox PL 2014 Programmed translational readthrough generates antiangiogenic VEGF-Ax. Cell 157 1605-1618. (doi:10.1016/j.cell.2014.04.033)

Ferrara N 2000 VEGF: an update on biological and therapeutic aspects. Current Opinion in Biotechnology 11 617-624. (doi:10.1016/S09581669(00)00153-1)

Ferrara N 2010 Pathways mediating VEGF-independent tumor angiogenesis. Cytokine \& Growth Factor Reviews 21 21-26. (doi:10.1016/j.cytogfr. 2009.11.003)

Ferrara N, Carver-Moore K, Chen H, Dowd M, Lu L, O'Shea KS, PowellBraxton L, Hillan KJ \& Moore MW 1996 Heterozygous embryonic lethality induced by targeted inactivation of the VEGF gene. Nature $\mathbf{3 8 0}$ 439-442. (doi:10.1038/380439a0)

Ferrara N, Gerber HP \& LeCouter J 2003 The biology of VEGF and its receptors. Nature Medicine 9 669-676. (doi:10.1038/nm0603-669)

Fong GH, Rossant J, Gertsenstein M \& Breitman ML 1995 Role of the Flt-1 receptor tyrosine kinase in regulating the assembly of vascular endothelium. Nature 376 66-70. (doi:10.1038/376066a0)

Fuh G, Li B, Crowley C, Cunningham B \& Wells JA 1998 Requirements for binding and signaling of the kinase domain receptor for vascular endothelial growth factor. Journal of Biological Chemistry $\mathbf{2 7 3}$ 11197-11204. (doi:10.1074/jbc.273.18.11197)

Gerber HP, Condorelli F, Park J \& Ferrara N 1997 Differential transcriptional regulation of the two vascular endothelial growth factor receptor genes, Flt-1, but not Flk-1/KDR, is up-regulated by hypoxia. Journal of Biological Chemistry 272 23659-23667. (doi:10.1074/jbc.272.38.23659)

Gerena RL, Eguchi N, Urade Y \& Killian GJ 2000a Stage and region-specific localization of lipocalin-type prostaglandin D synthase in the adult murine testis and epididymis. Journal of Andrology 21 848-854.

Gerena RL, Irikura D, Eguchi N, Urade Y \& Killian GJ 2000b Immunocytochemical localization of lipocalin-type prostaglandin D synthase in the bull testis and epididymis and on ejaculated sperm. Biology of Reproduction 62 547-556. (doi:10.1095/biolreprod62.3.547)

Giacca M 2010 Non-redundant functions of the protein isoforms arising from alternative splicing of the VEGF-A pre-mRNA. Transcription $\mathbf{1}$ 149-153. (doi:10.4161/trns.1.3.13229)

Gille H, Kowalski J, Yu L, Chen H, Pisabarro MT, Davis-Smyth T \& Ferrara N 2000 A repressor sequence in the juxtamembrane domain of Flt-1 (VEGFR-1) constitutively inhibits vascular endothelial growth factordependent phosphatidylinositol 3'-kinase activation and endothelial cell migration. Embo Journal 19 4064-4073. (doi:10.1093/emboj/19.15. 4064)

Gille H, Kowalski J, Li B, LeCouter J, Moffat B, Zioncheck TF, Pelletier N \& Ferrara N 2001 Analysis of biological effects and signaling properties of Flt-1 (VEGFR-1) and KDR (VEGFR-2). A reassessment using novel receptor-specific vascular endothelial growth factor mutants. Journal of Biological Chemistry 276 3222-3230. (doi:10.1074/jbc.M002016200)

Groos S, Krause W \& Mueller UO 2006 Men with subnormal sperm counts live shorter lives. Social Biology 53 46-60. (doi:10.1080/19485565.2006. 9989116)

Grunstein J, Masbad JJ, Hickey R, Giordano F \& Johnson RS 2000 Isoforms of vascular endothelial growth factor act in a coordinate fashion To recruit and expand tumor vasculature. Molecular and Cellular Biology 20 7282-7291. (doi:10.1128/MCB.20.19.7282-7291.2000)
Harley VR, Clarkson MJ \& Argentaro A 2003 The molecular action and regulation of the testis-determining factors, SRY (sex-determining region on the Y chromosome) and SOX9 [SRY-related high-mobility group (HMG) box 9]. Endocrine Reviews 24 466-487. (doi:10.1210/er. 2002-0025)

Harris S, Craze M, Newton J, Fisher M, Shima DT, Tozer GM \& Kanthou C 2012 Do anti-angiogenic VEGF (VEGFxxxb) isoforms exist? A cautionary tale PLOS ONE 7 e35231. (doi:10.1371/journal.pone.0035231)

He Z \& Tessier-Lavigne M 1997 Neuropilin is a receptor for the axonal chemorepellent Semaphorin III. Cell 90 739-751. (doi:10.1016/S00928674(00)80534-6)

Heldin CH 2013 Targeting the PDGF signaling pathway in tumor treatment. Cell Communication and Signaling 11 97. (doi:10.1186/1478811X-11-97)

Hellstrom M, Kalen M, Lindahl P, Abramsson A \& Betsholtz C 1999 Role of PDGF-B and PDGFR- $\beta$ in recruitment of vascular smooth muscle cells and pericytes during embryonic blood vessel formation in the mouse. Development 126 3047-3055.

Hiratsuka S, Minowa O, Kuno J, Noda T \& Shibuya M 1998 Flt-1 lacking the tyrosine kinase domain is sufficient for normal development and angiogenesis in mice. PNAS 95 9349-9354. (doi:10.1073/pnas.95. 16.9349)

Hiratsuka S, Maru Y, Okada A, Seiki M, Noda T \& Shibuya M 2001 Involvement of Flt-1 tyrosine kinase (vascular endothelial growth factor receptor-1) in pathological angiogenesis. Cancer Research $\mathbf{6 1}$ 1207-1213.

Hoeben A, Landuyt B, Highley MS, Wildiers H, Van Oosterom AT \& De Bruijn EA 2004 Vascular endothelial growth factor and angiogenesis. Pharmacological Reviews 56 549-580. (doi:10.1124/pr.56.4.3)

Houck KA, Ferrara N, Winer J, Cachianes G, Li B \& Leung DW 1991 The vascular endothelial growth factor family: identification of a fourth molecular species and characterization of alternative splicing of RNA. Molecular Endocrinolgy 5 1806-1814. (doi:10.1210/mend-5-12-1806)

Iniguez MA, Rodriguez A, Volpert OV, Fresno M \& Redondo JM 2003 Cyclooxygenase-2: a therapeutic target in angiogenesis. Trends in Molecular Medicine 9 73-78. (doi:10.1016/S1471-4914(02)00011-4)

Jaffredo T, Nottingham W, Liddiard K, Bollerot K, Pouget C \& de Bruijn M 2005 From hemangioblast to hematopoietic stem cell: an endothelial connection? Experimental Hematology 33 1029-1040. (doi:10.1016/ j.exphem.2005.06.005)

Jameson SA, Lin YT \& Capel B 2012 Testis development requires the repression of Wnt4 by Fgf signaling. Developmental Biology 370 24-32. (doi:10.1016/j.ydbio.2012.06.009)

Jeays-Ward K, Hoyle C, Brennan J, Dandonneau M, Alldus G, Capel B \& Swain A 2003 Endothelial and steroidogenic cell migration are regulated by WNT4 in the developing mammalian gonad. Development 130 3663-3670. (doi:10.1242/dev.00591)

Juul A, Almstrup K, Andersson AM, Jensen TK, Jorgensen N, Main KM, Rajpert-De Meyts E, Toppari J \& Skakkebaek NE 2014 Possible fetal determinants of male infertility. Nature Reviews. Endocrinology 10 553-562. (doi:10.1038/nrendo.2014.97)

Kajdaniuk D, Marek B, Borgiel-Marek H \& Kos-Kudla B 2011 Vascular endothelial growth factor (VEGF) - part 1: in physiology and pathophysiology. Endokrynologia Polska 62 444-455.

Kawamura H, Li X, Harper SJ, Bates DO \& Claesson-Welsh L 2008 Vascular endothelial growth factor (VEGF)-A165b is a weak in vitro agonist for VEGF receptor-2 due to lack of coreceptor binding and deficient regulation of kinase activity. Cancer Research 68 4683-4692. (doi:10.1158/0008-5472.CAN-07-6577)

Kawasaki T, Kitsukawa T, Bekku Y, Matsuda Y, Sanbo M, Yagi T \& Fujisawa H 1999 A requirement for neuropilin-1 in embryonic vessel formation. Development 126 4895-4902.

Kearney JB, Kappas NC, Ellerstrom C, DiPaola FW \& Bautch VL 2004 The VEGF receptor flt-1 (VEGFR-1) is a positive modulator of vascular sprout formation and branching morphogenesis. Blood 103 4527-4535. (doi:10.1182/blood-2003-07-2315) 
Keyt BA, Nguyen HV, Berleau LT, Duarte CM, Park J, Chen H \& Ferrara N 1996 Identification of vascular endothelial growth factor determinants for binding KDR and FLT-1 receptors. Generation of receptor-selective VEGF variants by site-directed mutagenesis. Journal of Biological Chemistry 271 5638-5646. (doi:10.1074/jbc.271.10.5638)

Kim Y, Kobayashi A, Sekido R, DiNapoli L, Brennan J, Chaboissier MC, Poulat F, Behringer RR, Lovell-Badge R \& Capel B 2006 Fgf9 and Wnt4 act as antagonistic signals to regulate mammalian sex determination. PLoS Biology 4 e187. (doi:10.1371/journal.pbio.0040187)

Kobayashi A, Chang H, Chaboissier MC, Schedl A \& Behringer RR 2005 Sox9 in testis determination. Annals of New York Academy of Sciences 1061 9-17. (doi:10.1196/annals.1336.003)

Konopatskaya O, Churchill AJ, Harper SJ, Bates DO \& Gardiner TA 2006 VEGF165b, an endogenous C-terminal splice variant of VEGF, inhibits retinal neovascularization in mice. Molecular Vision 12 626-632.

Korpelainen EI, Karkkainen MJ, Tenhunen A, Lakso M, Rauvala H, Vierula M, Parvinen M \& Alitalo K 1998 Overexpression of VEGF in testis and epididymis causes infertility in transgenic mice: evidence for nonendothelial targets for VEGF. Journal of Cell Biology 143 1705-1712. (doi:10.1083/jcb.143.6.1705)

Krilleke D, Ng YS \& Shima DT 2009 The heparin-binding domain confers diverse functions of VEGF-A in development and disease: a structurefunction study. Biochemical Society Transactions 37 1201-1206. (doi:10. 1042/BST0371201)

Kristensen DM, Hass U, Lesne L, Lottrup G, Jacobsen PR, DesdoitsLethimonier C, Boberg J, Petersen JH, Toppari J, Jensen TK et al. 2011 a Intrauterine exposure to mild analgesics is a risk factor for development of male reproductive disorders in human and rat. Human Reproduction 26 235-244. (doi:10.1093/humrep/deq323)

Kristensen DM, Skalkam ML, Audouze K, Lesne L, Desdoits-Lethimonier C, Frederiksen H, Brunak S, Skakkebaek NE, Jegou B, Hansen JB et al. 2011 b Many putative endocrine disruptors inhibit prostaglandin synthesis. Environmental Health Perspectives 119 534-541. (doi:10.1289/ehp. 1002635)

Kristensen DM, Lesne L, Le Fol V, Desdoits-Lethimonier C, DejucqRainsford N, Leffers H \& Jegou B 2012 Paracetamol (acetaminophen), aspirin (acetylsalicylic acid) and indomethacin are anti-androgenic in the rat foetal testis. International Journal of Andrology 35 377-384. (doi:10.1111/j.1365-2605.2012.01282.x)

Kriz V, Agren N, Lindholm CK, Lenell S, Saldeen J, Mares J \& Welsh M 2006 The SHB adapter protein is required for normal maturation of mesoderm during in vitro differentiation of embryonic stem cells. Journal of Biological Chemistry 281 34484-34491. (doi:10.1074/jbc. M604084200)

Kroll J \& Waltenberger J 1997 The vascular endothelial growth factor receptor KDR activates multiple signal transduction pathways in porcine aortic endothelial cells. Journal of Biological Chemistry 272 32521-32527. (doi:10.1074/jbc.272.51.32521)

Kukk E, Lymboussaki A, Taira S, Kaipainen A, Jeltsch M, Joukov V \& Alitalo K 1996 VEGF-C receptor binding and pattern of expression with VEGFR-3 suggests a role in lymphatic vascular development. Development 122 3829-3837.

Lamalice L, Houle F, Jourdan G \& Huot J 2004 Phosphorylation of tyrosine 1214 on VEGFR2 is required for VEGF-induced activation of Cdc42 upstream of SAPK2/p38. Oncogene 23 434-445. (doi:10.1038/sj.onc. 1207034)

Lee S, Jilani SM, Nikolova GV, Carpizo D \& Iruela-Arispe ML 2005 Processing of VEGF-A by matrix metalloproteinases regulates bioavailability and vascular patterning in tumors. Journal of Cell Biology 169 681-691. (doi:10.1083/jcb.200409115)

Lee SH, Jeong D, Han YS \& Baek MJ 2015 Pivotal role of vascular endothelial growth factor pathway in tumor angiogenesis. Annals of Surgical Treatment and Research 89 1-8. (doi:10.4174/astr.2015.89.1.1)

Leveen P, Pekny M, Gebre-Medhin S, Swolin B, Larsson E \& Betsholtz C 1994 Mice deficient for PDGF B show renal, cardiovascular, and hematological abnormalities. Genes and Development 8 1875-1887. (doi:10.1101/gad.8.16.1875)

Levine E, Cupp AS \& Skinner MK 2000 Role of neurotropins in rat embryonic testis morphogenesis (cord formation). Biology of Reproduction 62 132-142. (doi:10.1095/biolreprod62.1.132)

Lindahl P, Johansson BR, Leveen P \& Betsholtz C 1997 Pericyte loss and microaneurysm formation in PDGF-B-deficient mice. Science 277 242-245. (doi:10.1126/science.277.5323.242)

Lu N, Sargent KM, Clopton DT, Pohlmeier WE, Brauer VM, McFee RM, Weber JS, Ferrara N, Silversides DW \& Cupp AS 2013 Loss of vascular endothelial growth factor A (VEGFA) isoforms in the testes of male mice causes subfertility. Reduces sperm numbers, and alters expression of genes that regulate undifferentiated spermatogonia. Endocrinology 154 4790-4802. (doi:10.1210/en.2013-1363)

Magre S \& Jost A 1991 Sertoli cells and testicular differentiation in the rat fetus. Journal of Electron Microscopy Technique 19 172-188. (doi:10.1002/ jemt.1060190205)

Matlin AJ, Clark F \& Smith CW 2005 Understanding alternative splicing: towards a cellular code. Nature Review. Molecular and Cellular Biology 6 386-398. (doi:10.1038/nrm1645)

McFee RM, Artac RA, McFee RM, Clopton DT, Longfellow Smith RA, Rozell TG \& Cupp AS 2009 Inhibition of vascular endothelial growth factor receptor signal transduction blocks follicle progression but does not necessarily disrupt vascular development in perinatal rat ovaries. Biology of Reproduction 81 966-977. (doi:10.1095/biolreprod.109. 078071)

Medvinsky A, Rybtsov S \& Taoudi S 2011 Embryonic origin of the adult hematopoietic system: advances and questions. Development 138 1017-1031. (doi:10.1242/dev.040998)

Miao HQ, Soker S, Feiner L, Alonso JL, Raper JA \& Klagsbrun M 1999 Neuropilin-1 mediates collapsin-1/semaphorin III inhibition of endothelial cell motility: functional competition of collapsin-1 and vascular endothelial growth factor-165. Journal of Cell Biology 146 233-242. (doi:10.1083/jcb.146.1.233)

Mineur P, Colige AC, Deroanne CF, Dubail J, Kesteloot F, Habraken Y, Noel A, Voo S, Waltenberger J, Lapiere CM et al. 2007 Newly identified biologically active and proteolysis-resistant VEGF-A isoform VEGF111 is induced by genotoxic agents. Journal of Cell Biology 179 1261-1273. (doi:10.1083/jcb.200703052)

Mintz B \& Russell ES 1957 Gene-induced embryological modifications of primordial germ cells in the mouse. Journal of Experimental Zoology 134 207-237. (doi:10.1002/jez.1401340202)

Moniot B, Declosmenil F, Barrionuevo F, Scherer G, Aritake K, Malki S, Marzi L, Cohen-Solal A, Georg I, Klattig J et al. 2009 The PGD2 pathway, independently of FGF9, amplifies SOX9 activity in Sertoli cells during male sexual differentiation. Development 136 1813-1821. (doi:10.1242/ dev.032631)

Munger SC \& Capel B 2012 Sex and the circuitry: progress toward a systemslevel understanding of vertebrate sex determination. Wiley Interdisciplinary Reviews. Systems Biology and Medicine 4 401-412. (doi:10.1002/ wsbm.1172)

Murray PDF 1932 The development in vitro of the blood of the early chick embryo. Proceedings of the Royal Society of London. Series B, Containing Papers of a Biological Character. Royal Society 111 497-521. (doi:10.1098/ rspb.1932.0070)

Nocka K, Majumder S, Chabot B, Ray P, Cervone M, Bernstein A \& Besmer P 1989 Expression of c-kit gene products in known cellular targets of W mutations in normal and $\mathrm{W}$ mutant mice - evidence for an impaired c-kit kinase in mutant mice. Genes and Development 3 816-826. (doi:10.1101/gad.3.6.816)

Olofsson B, Korpelainen E, Pepper MS, Mandriota SJ, Aase K, Kumar V Gunji Y, Jeltsch MM, Shibuya M, Alitalo K et al. 1998 Vascular endothelial growth factor B (VEGF-B) binds to VEGF receptor-1 and regulates plasminogen activator activity in endothelial cells. PNAS 95 11709-11714. (doi:10.1073/pnas.95.20.11709) http://joe.endocrinology-journals.org DOI: $10.1530 / J O E-15-0342$
() 2015 Society for Endocrinology Printed in Great Britain 
Olofsson B, Jeltsch M, Eriksson U \& Alitalo K 1999 Current biology of VEGF-B and VEGF-C. Current Opinion in Biotechnology 10 528-535. (doi:10.1016/S0958-1669(99)00024-5)

Ozdzenski W 1969 Fate of primordial germ cells in the transplanted hind gut of mouse embryos. Journal of Embryology and Experimental Morphology 22 505-510.

Pai R, Szabo IL, Soreghan BA, Atay S, Kawanaka H \& Tarnawski AS 2001 PGE(2) stimulates VEGF expression in endothelial cells via ERK2/JNK1 signaling pathways. Biochemical and Biophysical Research Communication 286 923-928. (doi:10.1006/bbrc.2001.5494)

Pan Q, Chathery Y, Wu Y, Rathore N, Tong RK, Peale F, Bagri A, TessierLavigne M, Koch AW \& Watts RJ 2007 Neuropilin-1 binds to VEGF121 and regulates endothelial cell migration and sprouting. Journal of Biological Chemistry 282 24049-24056. (doi:10.1074/jbc.M703554200)

Parma P, Pailhoux E \& Cotinot C 1999 Reverse transcription-polymerase chain reaction analysis of genes involved in gonadal differentiation in pigs. Biology of Reproduction 61 741-748. (doi:10.1095/biolreprod61. 3.741)

Patek CE, Kerr JB, Gosden RG, Jones KW, Hardy K, Muggleton-Harris AL, Handyside AH, Whittingham DG \& Hooper ML 1991 Sex chimaerism, fertility and sex determination in the mouse. Development 113 311-325.

Payen E, Pailhoux E, Abou Merhi R, Gianquinto L, Kirszenbaum M, Locatelli A \& Cotinot C 1996 Characterization of ovine SRY transcript and developmental expression of genes involved in sexual differentiation. International Journal of Developmental Biology 40 567-575.

Pelliniemi LJ \& Lauteala L 1981 Development of sexual dimorphism in the embryonic gonad. Human Genetics 58 64-67. (doi:10.1007/ BF00284151)

Perala NM, Immonen T \& Sariola H 2005 The expression of plexins during mouse embryogenesis. Gene Expression Patterns 5 355-362. (doi:10.1016/j.modgep.2004.10.001)

Puglianiello A, Campagnolo L, Farini D, Cipollone D, Russo MA \& Siracusa G 2004 Expression and role of PDGF-BB and PDGFR- $\beta$ during testis morphogenesis in the mouse embryo. Journal of Cell Science $\mathbf{1 1 7}$ 1151-1160. (doi:10.1242/jcs.00981)

Qiu Y, Hoareau-Aveilla C, Oltean S, Harper SJ \& Bates DO 2009 The anti-angiogenic isoforms of VEGF in health and disease. Biochemical Society Transactions 37 1207-1213. (doi:10.1042/BST0371207)

Rajagopal K, Sommers CL, Decker DC, Mitchell EO, Korthauer U, Sperling AI, Kozak CA, Love PE \& Bluestone JA 1999 RIBP, a novel Rlk/Txk- and itk-binding adaptor protein that regulates $\mathrm{T}$ cell activation. Journal of Experimental Medicine 190 1657-1668. (doi:10.1084/jem.190.11.1657)

Rossitto M, Ujjan S, Poulat F \& Boizet-Bonhoure B 2015 Multiple roles of the prostaglandin D2 signaling pathway in reproduction. Reproduction 149 R49-R58. (doi:10.1084/jem.190.11.1657)

Runyan C, Schaible K, Molyneaux K, Wang Z, Levin L \& Wylie C 2006 Steel factor controls midline cell death of primordial germ cells and is essential for their normal proliferation and migration. Development 133 4861-4869. (doi:10.1242/dev.02688)

Russo MA, Giustizieri ML, Favale A, Fantini MC, Campagnolo L, Konda D, Germano F, Farini D, Manna C \& Siracusa G 1999 Spatiotemporal patterns of expression of neurotrophins and neurotrophin receptors in mice suggest functional roles in testicular and epididymal morphogenesis. Biology of Reproduction 61 1123-1132. (doi:10.1095/biolreprod61.4.1123)

Sakurai Y, Ohgimoto K, Kataoka Y, Yoshida N \& Shibuya M 2005 Essential role of Flk-1 (VEGF receptor 2) tyrosine residue 1173 in vasculogenesis in mice. PNAS 102 1076-1081. (doi:10.1073/pnas.0404984102)

Seetharam L, Gotoh N, Maru Y, Neufeld G, Yamaguchi S \& Shibuya M 1995 A unique signal transduction from FLT tyrosine kinase, a receptor for vascular endothelial growth factor VEGF. Oncogene 10 135-147.

Seifi T, Ghaedi K, Salamian A, Tanhaei S, Safari F, Hojati Z, Tavassoli M, Baharvand H \& Esfahani MH 2012 Amplification of GC-rich putative mouse PeP promoter using $\beta$ ine and DMSO in ammonium sulfate polymerase chain reaction buffer. Avicenna Journal of Medical Biotechnology 4 206-209.

Sekido R \& Lovell-Badge R 2008 Sex determination involves synergistic action of SRY and SF1 on a specific Sox9 enhancer. Nature 453 930-934. (doi:10.1038/nature06944)

Selvaraj SK, Giri RK, Perelman N, Johnson C, Malik P \& Kalra VK 2003 Mechanism of monocyte activation and expression of proinflammatory cytochemokines by placenta growth factor. Blood 102 1515-1524. (doi:10.1182/blood-2002-11-3423)

Shalaby F, Rossant J, Yamaguchi TP, Gertsenstein M, Wu XF, Breitman ML \& Schuh AC 1995 Failure of blood-island formation and vasculogenesis in Flk-1-deficient mice. Nature 376 62-66. (doi:10.1038/376062a0)

Shan J, Jokela T, Peltoketo H \& Vainio S 2009 Generation of an allele to inactivate Wnt4 gene function conditionally in the mouse. Genesis $\mathbf{4 7}$ 782-788. (doi:10.1002/dvg.20566)

Shinkai A, Ito M, Anazawa H, Yamaguchi S, Shitara K \& Shibuya M 1998 Mapping of the sites involved in ligand association and dissociation at the extracellular domain of the kinase insert domain-containing receptor for vascular endothelial growth factor. Journal of Biological Chemistry 273 31283-31288. (doi:10.1074/jbc.273.47.31283)

Siggers P, Carre GA, Bogani D, Warr N, Wells S, Hilton H, Esapa C, Hajihosseini MK \& Greenfield A 2014 A novel mouse Fgfr2 mutant, hobbyhorse (hob), exhibits complete XY gonadal sex reversal. PLoS ONE 9 e100447. (doi:10.1371/journal.pone.0100447)

Simons M 2007 Silky, sticky chimeras-designer VEGFs display their wares. Circulation Research 100 1402-1404. (doi:10.1161/01.RES.0000269333. 10849.9e)

Soriano P 1994 Abnormal kidney development and hematological disorders in PDGF $\beta$-receptor mutant mice. Genes and Development 8 1888-1896. (doi:10.1101/gad.8.16.1888)

Takahashi T, Nakamura F, Jin Z, Kalb RG \& Strittmatter SM 1998 Semaphorins A and E act as antagonists of neuropilin-1 and agonists of neuropilin-2 receptors. Nature Neuroscience 1 487-493. (doi:10.1038/ 2203)

Tao Q, Backer MV, Backer JM \& Terman BI 2001 Kinase insert domain receptor (KDR) extracellular immunoglobulin-like domains 4-7 contain structural features that block receptor dimerization and vascular endothelial growth factor-induced signaling. Journal of Biological Chemistry 276 21916-21923. (doi:10.1074/jbc.M100763200)

Tesarik J, Martinez F, Rienzi L, Iacobelli M, Ubaldi F, Mendoza C \& Greco E 2002 In-vitro effects of FSH and testosterone withdrawal on caspase activation and DNA fragmentation in different cell types of human seminiferous epithelium. Human Reproduction 17 1811-1819. (doi:10.1093/humrep/17.7.1811)

Tilmann C \& Capel B 1999 Mesonephric cell migration induces testis cord formation and Sertoli cell differentiation in the mammalian gonad. Development 126 2883-2890.

Uzumcu M, Dirks KA \& Skinner MK 2002a Inhibition of platelet-derived growth factor actions in the embryonic testis influences normal cord development and morphology. Biology of Reproduction 66 745-753. (doi:10.1095/biolreprod66.3.745)

Uzumcu M, Westfall SD, Dirks KA \& Skinner MK $2002 b$ Embryonic testis cord formation and mesonephric cell migration requires the phosphotidylinositol 3-kinase signaling pathway. Biology of Reproduction 67 1927-1935. (doi:10.1095/biolreprod.102.006254)

Vainio S, Heikkila M, Kispert A, Chin N \& McMahon AP 1999 Female development in mammals is regulated by Wnt-4 signalling. Nature $\mathbf{3 9 7}$ 405-409. (doi:10.1038/17068)

Veikkola T \& Alitalo K 1999 VEGFs, receptors and angiogenesis. Seminars in Cancer Biology 9 211-220. (doi:10.1006/scbi.1998.0091)

Vieira JM, Ruhrberg C \& Schwarz Q 2010 VEGF receptor signaling in vertebrate development. Organogenesis 6 97-106. (doi:10.4161/org.6.2. 11686)

Wagener A, Blottner S, Göritz F, Streich WJ \& Fickel J 2010 Circannual changes in the expression of vascular endothelial growth factor in the

Published by Bioscientifica Ltd. 
testis of roe deer (Capreolus capreolus). Animal Reproduction Science 117 275-278. (doi:10.1016/j.anireprosci.2009.05.006)

Waltenberger J, Claesson-Welsh L, Siegbahn A, Shibuya M \& Heldin CH 1994 Different signal transduction properties of KDR and Flt1, two receptors for vascular endothelial growth factor. Journal of Biological Chemistry 269 26988-26995.

Wang L, Mukhopadhyay D \& Xu X 2006 C terminus of RGS-GAIPinteracting protein conveys neuropilin-1-mediated signaling during angiogenesis. FASEB Journal 20 1513-1515. (doi:10.1096/fj. 05-5504fje)

Werdich XQ \& Penn JS 2005 Src, Fyn and Yes play differential roles in VEGF-mediated endothelial cell events. Angiogenesis 8 315-326. (doi:10.1007/s10456-005-9021-x)

Wheeler-Jones C, Abu-Ghazaleh R, Cospedal R, Houliston RA, Martin J \& Zachary I 1997 Vascular endothelial growth factor stimulates prostacyclin production and activation of cytosolic phospholipase A2 in endothelial cells via p42/p44 mitogen-activated protein kinase. FEBS Letters 420 28-32. (doi:10.1016/S0014-5793(97)01481-6)

Wilhelm D, Hiramatsu R, Mizusaki H, Widjaja L, Combes AN, Kanai Y \& Koopman P 2007 SOX9 regulates prostaglandin D synthase gene transcription in vivo to ensure testis development. Journal of Biological Chemistry 282 10553-10560. (doi:10.1074/jbc.M609578200)

Woolard J, Wang WY, Bevan HS, Qui Y, Morbidelli L, Pritchard-Jones RO, Cui TG, Sugiono M, Waine E, Perrin R et al. 2004 VEGF165b, an inhibitory vascular endothelial growth factor splice variant: mechanism of action, in vivo effect on angiogenesis and endogenous protein expression. Cancer Research 64 7822-7835. (doi:10.1158/00085472.CAN-04-0934)

Zachary I \& Gliki G 2001 Signaling transduction mechanisms mediating biological actions of the vascular endothelial growth factor family. Cardiovascular Research 49 568-581. (doi:10.1016/S00086363(00)00268-6)

Received in final form 10 September 2015 Accepted 16 September 2015
() 2015 Society for Endocrinology Printed in Great Britain
Published by Bioscientifica Ltd. 